\title{
A model using marginal efficiency of investment to analyze carbon and nitrogen interactions in terrestrial ecosystems (ACONITE Version 1)
}

\author{
R. Q. Thomas ${ }^{1}$ and M. Williams ${ }^{2}$ \\ ${ }^{1}$ Department of Forest Resources and Environmental Conservation, Virginia Tech, Blacksburg, Virginia, 24061, USA \\ ${ }^{2}$ School of GeoSciences, University of Edinburgh, Edinburgh, and NERC National Centre for Earth Observation, \\ EH9 3JN, UK
}

Correspondence to: R. Q. Thomas (rqthomas@vt.edu) and M. Williams (mat.williams@ed.ac.uk)

Received: 26 February 2014 - Published in Geosci. Model Dev. Discuss.: 25 April 2014

Revised: 16 July 2014 - Accepted: 20 July 2014 - Published: 12 September 2014

\begin{abstract}
Carbon (C) and nitrogen (N) cycles are coupled in terrestrial ecosystems through multiple processes including photosynthesis, tissue allocation, respiration, $\mathrm{N}$ fixation, $\mathrm{N}$ uptake, and decomposition of litter and soil organic matter. Capturing the constraint of $\mathrm{N}$ on terrestrial $\mathrm{C}$ uptake and storage has been a focus of the Earth System Modeling community. However, there is little understanding of the tradeoffs and sensitivities of allocating $\mathrm{C}$ and $\mathrm{N}$ to different tissues in order to optimize the productivity of plants. Here we describe a new, simple model of ecosystem $\mathrm{C}-\mathrm{N}$ cycling and interactions (ACONITE), that builds on theory related to plant economics in order to predict key ecosystem properties (leaf area index, leaf $\mathrm{C}: \mathrm{N}, \mathrm{N}$ fixation, and plant $\mathrm{C}$ use efficiency) based on the outcome of assessments of the marginal change in net $\mathrm{C}$ or $\mathrm{N}$ uptake associated with a change in allocation of $\mathrm{C}$ or $\mathrm{N}$ to plant tissues. We simulated and evaluated steady-state ecosystem stocks and fluxes in three different forest ecosystems types (tropical evergreen, temperate deciduous, and temperate evergreen). Leaf $\mathrm{C}: \mathrm{N}$ differed among the three ecosystem types (temperate deciduous $<$ tropical evergreen $<$ temperature evergreen), a result that compared well to observations from a global database describing plant traits. Gross primary productivity (GPP) and net primary productivity (NPP) estimates compared well to observed fluxes at the simulation sites. Simulated N fixation at steady-state, calculated based on relative demand for $\mathrm{N}$ and the marginal return on $\mathrm{C}$ investment to acquire $\mathrm{N}$, was an order of magnitude higher in the tropical forest than in the temperate forest, consistent with observations. A sensitivity analysis revealed that parameterization of the relationship between leaf
\end{abstract}

$\mathrm{N}$ and leaf respiration had the largest influence on leaf area index and leaf $\mathrm{C}: \mathrm{N}$. A parameter governing how photosynthesis scales with day length had the largest influence on total vegetation C, GPP, and NPP. Multiple parameters associated with photosynthesis, respiration, and $\mathrm{N}$ uptake influenced the rate of $\mathrm{N}$ fixation. Overall, our ability to constrain leaf area index and allow spatially and temporally variable leaf $\mathrm{C}: \mathrm{N}$ can help address challenges simulating these properties in ecosystem and Earth System models. Furthermore, the simple approach with emergent properties based on coupled $\mathrm{C}-\mathrm{N}$ dynamics has potential for use in research that uses data-assimilation methods to integrate data on both the $\mathrm{C}$ and $\mathrm{N}$ cycles to improve $\mathrm{C}$ flux forecasts.

\section{Introduction}

Globally, the biogeochemical cycles of carbon (C) and nitrogen $(\mathrm{N})$ are the most significant in terms of magnitudes, anthropogenic impact, and climate feedbacks (Erisman et al., 2013; IPCC, 2013). These cycles are closely coupled, from local to global scales. For instance, rates of $\mathrm{C}$ fixation are sensitive to foliar N content (Reich et al., 1994; Street et al., 2012). Thus, high productivity farming is reliant on $\mathrm{N}$ inputs (Tilman et al., 2002), and production in many natural ecosystems is N-limited (Norby et al., 2010; Shaver and Chapin, 1995). Rates of autotrophic respiration are linked to plant tissue $\mathrm{N}$ content (Reich et al., 2006), so $\mathrm{N}$ content is linked to vegetation C use efficiency (Waring et al., 1998). 
Plant $\mathrm{N}$ uptake from soils depends on $\mathrm{C}$ investment into root systems and mycorrhizal associations (Drake et al., 2011), which also diverts allocation away from tissues that directly fix C. Plant-microbe associations use $\mathrm{C}$ as an energy source to fix atmospheric $\mathrm{N}$ into bioavailable forms, at globally significant magnitudes (Rastetter et al., 2001). Decomposition of plant litter and soils is closely determined by its $\mathrm{C}: \mathrm{N}$ ratio (litter quality) (Manzoni et al., 2010; McClaugherty et al., 1985). Underlying this $\mathrm{C} / \mathrm{N}$ coupling in the biosphere, we can hypothesize that plants allocate $\mathrm{C}$ and $\mathrm{N}$ (to foliage, wood, roots, and symbiotes) to optimize returns on investment, i.e. C fixation and $\mathrm{N}$ uptake/fixation (Bloom et al., 1985; Hilbert and Reynolds, 1991).

The coupling of $\mathrm{C}$ and $\mathrm{N}$ in the biosphere interacts with global perturbations to the $\mathrm{C}$ and $\mathrm{N}$ cycles that have resulted from fossil fuel burning, production of $\mathrm{N}$ fertilizers, and land use/land cover change (Gruber and Galloway, 2008; Le Quere et al., 2009). Furthermore, climate, a key factor controlling both the C and N cycles (Schimel et al., 1997), has been altered by changes to the atmospheric composition of C and N (IPCC, 2013; Pinder et al., 2012). Together, these changes to the Earth system have perturbed ecosystem processes, altered $\mathrm{C}$ and $\mathrm{N}$ cycling, and enhanced terrestrial sinks of $\mathrm{C}$. The adaptation of ecosystem processes and structures to these changes in $\mathrm{N}$ and $\mathrm{C}$ resource limitations is not well understood, and has led to considerable debate (de Vries et al., 2008; Magnani et al., 2007; Thomas et al., 2010).

We lack basic understanding of biogeochemical sensitivities and trade-offs, particularly in how vegetation adjusts $\mathrm{C}$ and $\mathrm{N}$ allocation, and thereby structure and function, when relative $\mathrm{C}$ and $\mathrm{N}$ resource limitations shift. Production ( $\mathrm{C}$ fixation) is sensitive to leaf traits such as foliar $\mathrm{N}$ and to ecosystem properties such as leaf area index (Shaver et al., 2007; Williams and Rastetter, 1999). These parameters show distinct temporal, geographic and successional variation (Kattge et al., 2011; Wright et al., 2004), and are sensitive to global change drivers (Nowak et al., 2004). Plant access to soil $\mathrm{N}$ depends on the balance between investment in roots for uptake versus $\mathrm{N}$ fixation, but is also dependent on litter $\mathrm{C}: \mathrm{N}$ ratio, due to interactions with soil microbes. Land surface models have been developed to include $\mathrm{C}-\mathrm{N}$ interactions (Gerber et al., 2010; Smith et al., 2014; Sokolov et al., 2008; Thornton et al., 2007; Wang et al., 2010; Wania et al., 2012; Xu and Prentice, 2008; Zaehle et al., 2010), but these are typically highly parameterized. For example, empirical parameterizations that describe maximum canopy size (leaf area index; LAI), leaf $\mathrm{C}: \mathrm{N}$ ratios, and tissue allocation patterns are common at the plant function type (PFT) scale in these models.

Our objective is to describe a new, simple model of ecosystem $\mathrm{C}-\mathrm{N}$ cycling and interactions, ACONITE (Analyzing CarbOn and Nitrogen Interactions in Terrestrial Ecosystems). The need for a new model derives from outstanding uncertainties over key sensitivities of the biosphere to global change, as outlined above. The model builds on theory related to plant economy and optimization (Bloom et al., 1985). Thus, (i) plants are able to store $\mathrm{C}$ and N; (ii) plants produce tissues until the marginal revenue from this increased production is equal to the marginal cost; (iii) allocation is adjusted by plants so resources equally limit growth; (iv) each plant process is limited by the same balance of internal reserves. This approach results in several novel model features. Firstly, the model does not include fixed parameters for maximum LAI or leaf $\mathrm{C}: \mathrm{N}$ - instead, these parameters emerge from the calculation of marginal returns calculated separately for $\mathrm{C}$ and $\mathrm{N}$ investments, and so can vary in response to forcing (climate, fertilization, disturbance). Secondly, the model approach determines the optimal conditions for investment in $\mathrm{N}$ fixation over investment in root structure, which can also vary in response to forcing. Thirdly, $\mathrm{C}$ use efficiency is an emergent property of the model, linked to relative investment of $\mathrm{N}$ into different plant tissues of varying $\mathrm{N}$ content.

We use a relatively simple model structure, building on an existing simple C cycle model, DALEC (Williams et al., 2005). Simple, fast-running models with minimal parameters are best suited for inclusions within a data assimilation (DA) framework where large ensemble runs are needed at global scales. DA allows effective evaluation and parameterization of model structures against broad and independent data sets (Keenan et al., 2011). In this paper we describe the model structure, a sensitivity analysis and an evaluation of model outcomes for temperate and tropical forcing. The model results are also discussed in the context of other $\mathrm{C}-\mathrm{N}$ interaction modeling approaches, and potential applications in the future.

\section{Methods}

\subsection{Model description}

The model operates at a daily resolution, resolving seasonal dynamics in $\mathrm{C}: \mathrm{N}$ interactions in response to climate forcing. Required climate data are daily maximum and minimum temperature $\left({ }^{\circ} \mathrm{C}\right)$ and total down-welling shortwave radiation $\left(\mathrm{MJ} \mathrm{m}^{-2} \mathrm{~d}^{-1}\right)$. In this implementation hydrology is not included, so the evaluations are for selected ecosystems with relatively low water stress. Atmospheric $\mathrm{CO}_{2}$ concentration is held at 2010 levels for the evaluations. The final forcing term is the rate of $\mathrm{N}$ deposition $\left(\mathrm{g} \mathrm{N} \mathrm{m}^{-2}\right.$ day $\left.^{-1}\right)$. Transient responses to altered forcing over multiple years are simulated, but our focus here is on evaluating the steady state conditions under consistent forcing, and exploring the role of marginal investment decisions in generating these steady states. The full model code, written in Fortran 90, can be found in the Supplement or by contacting the authors. 


\subsubsection{Model structure}

The model state variables are stocks of $\mathrm{C}$ and $\mathrm{N}$ in discrete vegetation and soil pools, linked by specified fluxes (Fig. 1). Plants are represented by respiratory, labile, bud, leaf, fine root and stem pools. These pools are similar to the DALEC v1 C model (Fox et al., 2009) except that the labile pool has been subdivided into a bud pool that stores $\mathrm{C}$ before allocation to leaves and a respiratory pool $\left(\mathrm{C}_{\mathrm{Ra}}\right)$ to maintain metabolism during periods of low or no photosynthesis. In the plant, most $\mathrm{C}$ pools have a matching $\mathrm{N}$ pool, and therefore a $\mathrm{C}: \mathrm{N}$ (i.e. ratio). The only exception is the $\mathrm{C}_{\mathrm{Ra}}$ pool, which stores $\mathrm{C}$ prior to autotrophic respiration. Dead organic matter pools are partitioned into litter, coarse woody debris (CWD) and soil organic matter (SOM), with matching $\mathrm{C}$ and $\mathrm{N}$ pools, and hence $\mathrm{C}: \mathrm{N}$. The addition of a $\mathrm{CWD}$ pool and two inorganic $\mathrm{N}$ pools $\left(\mathrm{NH}_{4}^{+}\right.$and $\left.\mathrm{NO}_{3}^{-}\right)$are key differences between the DALEC v1 and ACONITE models.

ACONITE simulates the accumulation of $\mathrm{C}$ (photosynthesis) and $\mathrm{N}$ (root $\mathrm{N}$ uptake, $\mathrm{N}$ fixation, and $\mathrm{N}$ retranslocation during leave senescence) into the labile $\mathrm{C}$ and $\mathrm{N}$ stores. Labile $\mathrm{C}$ and $\mathrm{N}$ are allocated to tissue growth. Labile $\mathrm{C}$ is also used for growth respiration, maintenance respiration, and $\mathrm{N}$ fixation. Turnover of plant tissues generates inputs of $\mathrm{C}$ and $\mathrm{N}$ to specific litter (from foliage and fine roots) or CWD (from stem turnover) pools. CWD pools have a specific temperature-controlled residence time, before being transferred to the $\mathrm{C}$ or $\mathrm{N}$ litter pools. The $\mathrm{C}$ litter pool undergoes decomposition into a SOM C pool, with a fraction of this turnover respired heterotrophically. The $\mathrm{N}$ litter pool decomposes into the SOM N pool. The SOM pools must maintain a fixed $\mathrm{C}: \mathrm{N}$, so adjustments are made to the fluxes of $\mathrm{N}$ between the SOM and inorganic pools and turnover rates of litter. Further details on these processes and their controls are provided below with some equations separated into components to ease understanding. Tables 1 and 2 describe the mass balance equations and fluxes used in ACONITE.

\subsubsection{Photosynthesis}

Photosynthesis (gross primary productivity: GPP) is determined using a modified version of a response surface model, ACM (Aggregated Canopy Model; Williams et al., 1997). ACM is an aggregated model, based on the responses of a detailed ecophysiological model, SPA (Soil-Plant-Atmosphere, Williams et al., 1996), to climate forcing. SPA has been evaluated globally, and for the purposes of this paper has been tested in both temperate forests (Williams et al., 2001) and tropical forests (Fisher et al., 2007). In SPA, photosynthesis is strongly determined by leaf area index (LAI, the surface available for light absorption), and total leaf $\mathrm{N}$ ( $\mathrm{N}_{\text {leaf }}$; which is correlated in SPA with the rates of carboxylation and electron transport). Sensitivity analyses of SPA estimates of photosynthesis (Williams and Rastetter, 1999) identified a strong interaction between LAI and $\mathrm{N}_{\text {leaf }}$, with photosynthesis maximized by a balanced allocation between these two canopy traits.

The inputs to ACM include the climate forcing data (temperature and radiation), atmospheric $\mathrm{CO}_{2}$ (constant in this study), soil moisture (constant in this study), leaf area index (LAI, linked to leaf $\mathrm{C}$ ) and total foliar $\mathrm{N}$ (both calculated in ACONITE). ACM has been calibrated to reproduce SPA photosynthesis, but using typically measured values of LAI and foliar N (Fox et al., 2009). For the purposes of ACONITE simulations, ACM estimates must also reproduce the declining return on investment linked to imbalanced allocation to LAI or foliar N (Williams and Rastetter, 1999). In the ACONITE version of ACM, photosynthetic capacity is reduced when the ratio of LAI to $\mathrm{N}_{\text {leaf }}$ declines. Thus, a canopy with a given $\mathrm{N}_{\text {leaf }}$ is more productive with a larger LAI. To achieve this, GPP is adjusted by a monotonically saturating function on the ratio LAI : $\mathrm{N}_{\text {leaf }}$ (Eq. 7), introducing a new parameter to ACM. When LAI : $\mathrm{N}_{\text {leaf }}$ is large, the adjustment tends to 1: as this ratio declines, the adjustment factor falls slowly at first, but then increasingly fast as $\mathrm{N}_{\text {leaf }}$ becomes concentrated in a smaller and smaller total leaf area. The parameters used in the photosynthesis sub-model are listed in Table 3.

Maximum photosynthesis is set by ACM (Eq. 3), but the actual photosynthesis is a function of the size of the labile $\mathrm{C}$ pool, and the capacity of the plants to store labile $\mathrm{C}$ (Eq. 38)

Photosynthesis $(G)$ is down-regulated (by a factor $X_{\mathrm{c}}$ ) according to the saturation status of the labile $\mathrm{C}$ store:

$$
\begin{aligned}
& X_{\mathrm{c}}= \\
& \begin{cases}\max \left(0,\left(1-\frac{\mathrm{C}_{\text {labile }}-\text { store }_{\operatorname{maxc}}}{\text { store }_{\operatorname{maxc}}}\right),\right. & \mathrm{C}_{\text {labile }}>\text { store }_{\operatorname{maxc}} \\
1.0, & \mathrm{C}_{\text {labile }} \leq \text { store }_{\operatorname{maxc}} .\end{cases}
\end{aligned}
$$

Gross primary productivity (GPP) only occurs if daily minimum air temperature $\left(T_{\min }\right)>0{ }^{\circ} \mathrm{C}$ :

$\mathrm{GPP}= \begin{cases}X_{\mathrm{c}} \mathrm{GPP}^{*}, & T_{\min }>0 \\ 0, & T_{\min } \leq 0 .\end{cases}$

This function is required because photosynthesis relies on a water supply from soil that is restricted when soil moisture is frozen and because photosynthetic apparatus is damaged by freezing conditions (Linder and Troeng, 1980). We use an air temperature threshold for simplicity, but acknowledge that soil temperature would provide more reliable forcing. Photosynthesis (before potential down-regulation by freezing temperatures and labile $\mathrm{C}$ saturation; GPP*) is a function of daily irradiance $\left(I, \mathrm{MJ} \mathrm{m}^{-2} \mathrm{~d}^{-1}\right)$, day-length $(\zeta$, hours), atmospheric $\left[\mathrm{CO}_{2}\right]\left(\mathrm{C}_{\mathrm{a}}, \mathrm{ppm}\right)$, estimated internal $\left[\mathrm{CO}_{2}\right]\left(\mathrm{C}_{\mathrm{i}}\right.$, $\mathrm{ppm})$, and a set of parameters $\left(\mathrm{acm}_{1-11}\right)$,

$\mathrm{GPP}^{*}=\frac{e_{0} I g_{\mathrm{c}}\left(\mathrm{C}_{\mathrm{a}}-\mathrm{C}_{\mathrm{i}}\right)}{e_{0} I+g_{\mathrm{c}}\left(\mathrm{C}_{\mathrm{a}}-\mathrm{C}_{\mathrm{i}}\right)}\left(\mathrm{acm}_{2} \zeta+\mathrm{acm}_{5}\right)$.

The light response parameter $\left(e_{0}\right)$ is adjusted by LAI ( $L=\mathrm{C}_{\text {leaf }} /$ lca, where lca is leaf carbon per area) to reflect 

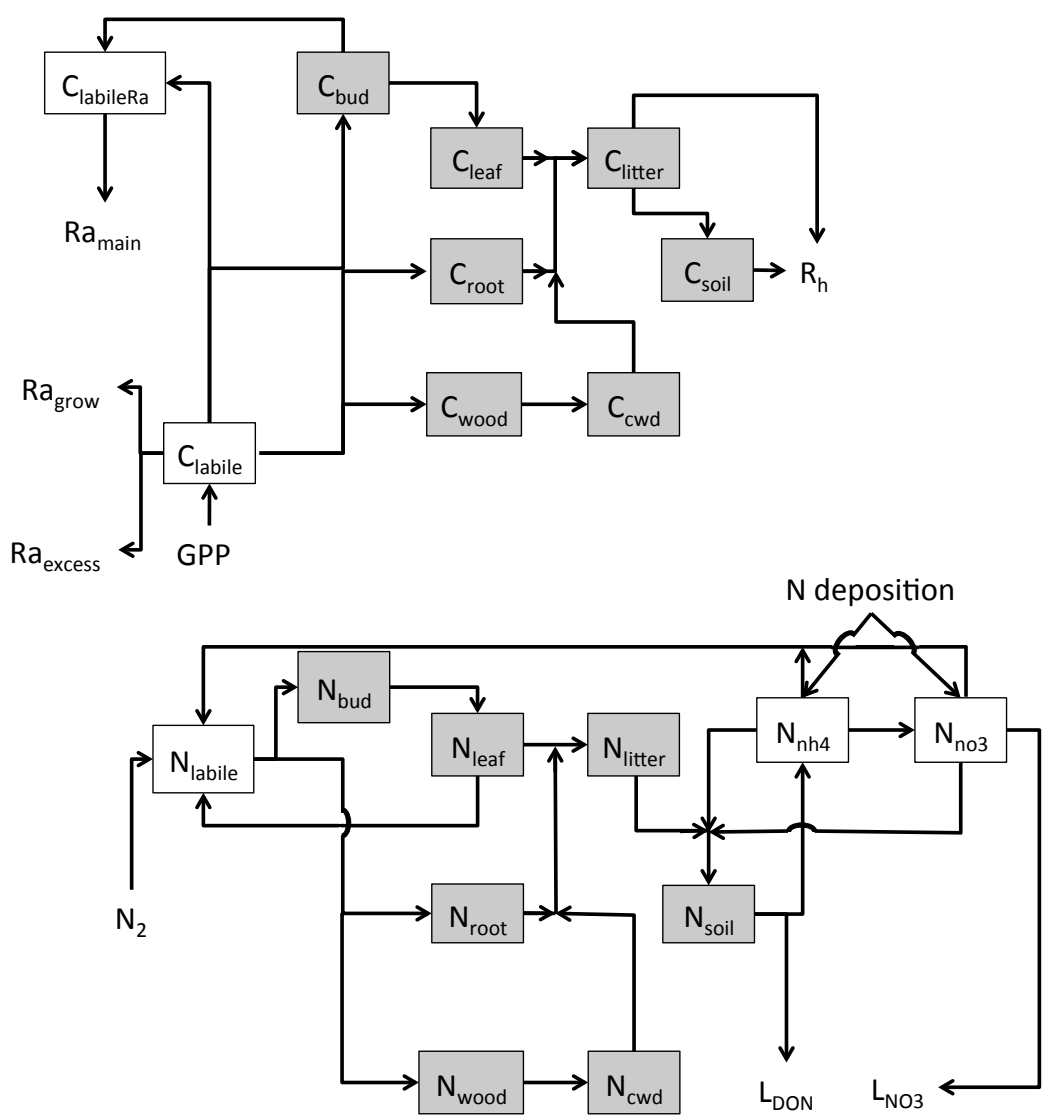

Figure 1. Structure of ACONITE, showing pools (boxes) and fluxes (arrows). The gray boxes are pool with C: $\mathrm{N}$ ratios. The top panel shows the $\mathrm{C}$ cycle, and the bottom panel shows the $\mathrm{N}$ cycle. All pools and flux correspond Tables 1 and $2 . R_{h}$ includes both litter $\left(t_{\text {litterC_atm }}\right)$ and soil C $\left(t_{\text {soil_atm }}\right)$ respiration fluxes. CWD $=$ coarse wood debris.

self-shading,

$e_{0}=\frac{\mathrm{acm}_{7} L^{2}}{L^{2}+\mathrm{acm}_{9}}$.

And $\mathrm{C}_{\mathrm{i}}$ is determined by a quadratic solution,

$\mathrm{C}_{\mathrm{i}}=0.5\left[\mathrm{C}_{\mathrm{a}}+q-p+\sqrt{\left(\left(\mathrm{C}_{\mathrm{a}}+q-p\right)^{2}-4\left(\mathrm{C}_{\mathrm{a}} q-\mathrm{acm}_{3} p\right)\right)}\right]$,

where

$q=\mathrm{acm}_{3}-\mathrm{acm}_{4}$.

Canopy photosynthetic capacity $(p)$ is linked to total foliar $\mathrm{N}\left(\mathrm{N}_{\text {leaf }}\right)$, canopy conductance $\left(g_{\mathrm{c}}\right)$, and maximum daily air temperature $\left(T_{\max }\right)$ but is adjusted by the ratio of LAI : $\mathrm{N}_{\text {leaf }}$ (see above),

$p=\frac{\mathrm{acm}_{1} \mathrm{~N}_{\text {leaf }}}{g_{\mathrm{c}}} e^{\mathrm{acm}_{8} T_{\mathrm{max}}} \frac{\mathrm{LAI}: \mathrm{N}_{\text {leaf }}}{\mathrm{LAI}: \mathrm{N}_{\text {leaf }}+\mathrm{acm}_{11}}$.

Canopy conductance $\left(g_{\mathrm{c}}\right)$ is a function of the difference between soil water potential and plant wilting point $\left(\Psi_{\mathrm{d}}\right)$, the hydraulic resistance of the soil-plant continuum $\left(R_{\mathrm{tot}}\right)$, and the maximum and minimum air temperature $\left(T_{\max / \min },{ }^{\circ} \mathrm{C}\right)$,

$$
g_{\mathrm{c}}=\frac{\left|\psi_{\mathrm{d}}\right|^{\mathrm{acm}_{10}}}{\left(\mathrm{acm}_{6} R_{\mathrm{tot}}+0.5\left(T_{\max }-T_{\min }\right)\right)} .
$$

\subsubsection{Plant $\mathrm{N}$ uptake}

Plant nutrient uptake is simulated using an existing model of solute uptake at steady state (Nye and Tinker, 1977; Williams and Yanai, 1996). Active uptake of $\mathrm{N}$ occurs at root surfaces with diffusion and solution flow supplying $\mathrm{N}$ to determine the rooting zone concentration. The model is applied individually for the uptake of both $\mathrm{NH}_{4}^{+}$or $\mathrm{NO}_{3}^{-}$to generate a total $\mathrm{N}$ uptake. The parameters governing $\mathrm{N}$ uptake are found in Table 4.

The rooting zone nutrient concentration $\left(\mathrm{C}_{\mathrm{av}}, \mathrm{mmol} \mathrm{m}^{-3}\right)$ is calculated as the mineral $\mathrm{N}\left(\mathrm{N}\right.$, which is either $\mathrm{NH}_{4}^{+}$or $\left.\mathrm{NO}_{3}^{-}\right)$pools distributed over a defined rooting depth $\left(r_{\text {depth }}\right)$, with molar conversions:

$\mathrm{C}_{\mathrm{av}}=\frac{\mathrm{N}}{r_{\text {depth }}} \frac{1000}{14}$. 
Table 1. Mass balance equations used in ACONITE.

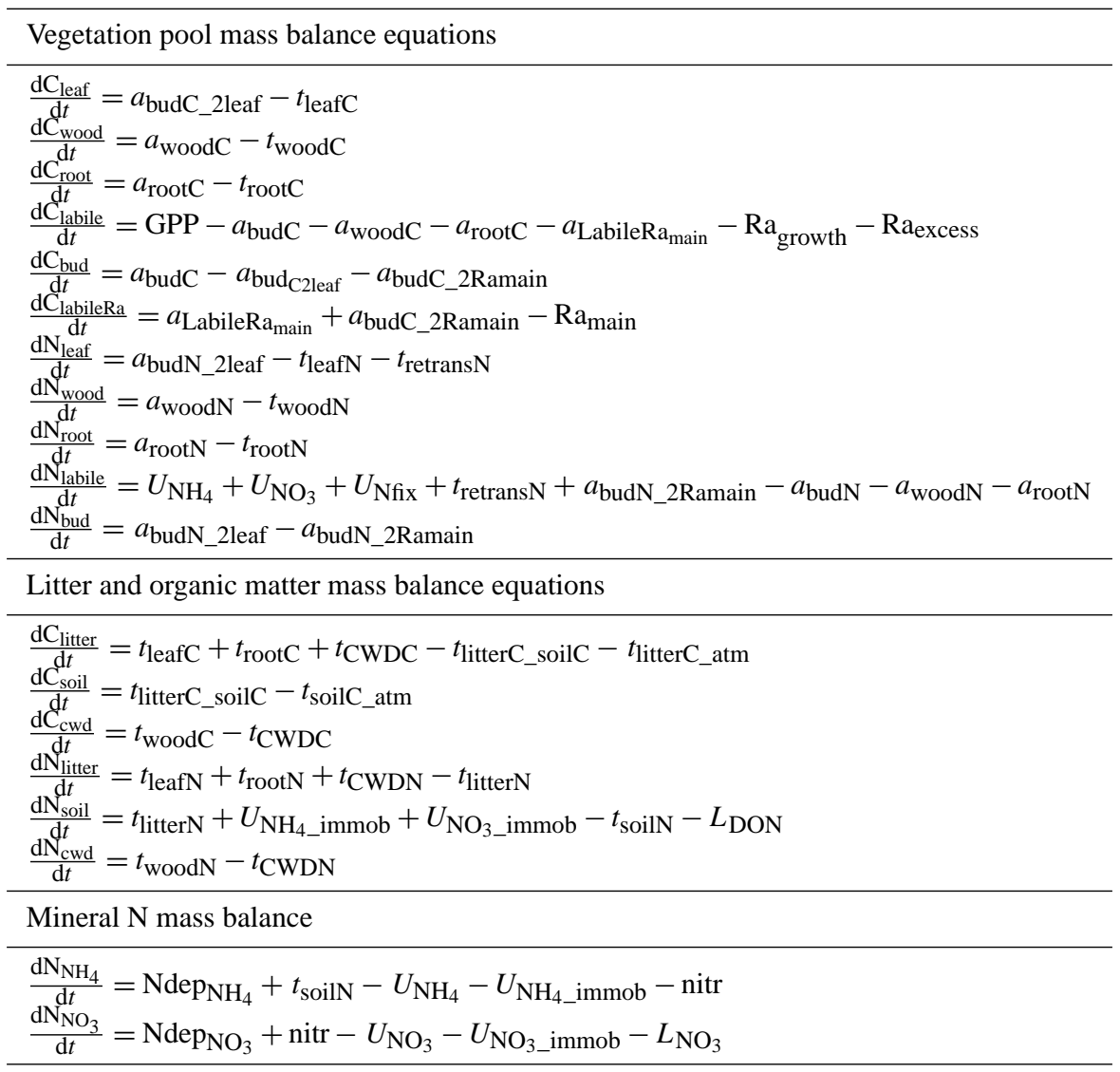

Uptake rate of $\mathrm{N}\left(U_{\mathrm{N}}\right)$ is a function of the root surface area $\left(r_{\text {surfarea }}\right)$, root absorbing power $(\alpha$; Eq. 14), the air temperature $\left(T_{\mathrm{a}}\right)$ adjusted maximum rate of uptake $\left(I_{\text {temp }} ;\right.$ Eq. 16$)$, and the degree of down-regulation of uptake ( $X_{\mathrm{N}}$; Eq. 20), multiplied by the number of seconds in a day $(S=86400)$ to provide daily mass values. Specific parameters are used for $\mathrm{NH}_{4}^{+}$or $\mathrm{NO}_{3}^{-}$:

$U_{\mathrm{N}}=r_{\text {surfarea }} \alpha I_{\text {temp }} X_{\mathrm{N}} S$.

Root surface area is a function of root radius ( $\left.r_{\text {radius }}\right)$ and root length ( $\left.r_{\text {length }}\right)$,

$r_{\text {surfarea }}=2 \pi r_{\text {radius }} r_{\text {length }}$.

Root length depends ( $r_{\text {length}}$ ) on the variable fine root $\mathrm{C}$ stock $\left(\mathrm{C}_{\text {root }}\right), \mathrm{C}$ concentration of biomass $\left(c_{\text {conc }}\right)$ and the volumetric mass density of biomass $\left(r_{\text {density }}\right)$

$r_{\text {length }}=\frac{\mathrm{C}_{\text {root }}}{c_{\text {conc }} r_{\text {density }} \pi r_{\text {radius }}^{2}}$.

The mean half distance between roots $\left(r_{x}\right)$ is

$r_{x}=\sqrt{\frac{r_{\text {depth }}}{\pi r_{\text {length }}}}$.
The root absorbing power $(\alpha)$ is determined by the concentration of solute at the root surface at steady state $\left(c_{o}\right)$ and the half saturation constant for uptake $\left(K_{m}\right)$

$\alpha=\frac{c_{o}}{K_{m}+c_{o}}$

and the solute concentration is determined as a quadratic solution for the steady state condition, requiring as inputs the temperature modified maximum rate of uptake ( $\left.I_{\text {temp }}\right)$, the inward radial velocity of water at the root surface $\left(v_{o}\right.$; Eq. 19), a factor $(\gamma$; Eq. 18) related to diffusion coefficients $(D)$ and buffering $(\beta)$ specific to the solute type, and a dimension factor $(\delta ;$ Eq. 17) linked to root structure,

$c_{o}=\frac{1}{2 \delta v_{0}}$

$\left(-I_{\text {temp }}+\delta I_{\text {temp }}+c_{\mathrm{av}} v_{0}-\delta \mathrm{k}_{m} v_{0}+\right.$

$\left.\sqrt{4 c_{\mathrm{av}} \delta \mathrm{k}_{m} v_{0}^{2}+\left(-I_{\mathrm{temp}}+\delta I_{\mathrm{temp}}+c_{\mathrm{av}} v_{0}-\delta \mathrm{K}_{m} v_{0}\right)^{2}}\right)$.

$I_{\text {temp }}$ is determined from the maximum rate of uptake at $20{ }^{\circ} \mathrm{C}, I_{\max }$, modified by a $Q_{10}$ function $\left(Q_{\mathrm{a}}\right)$ adjusted by average daily air temperature $\left(T_{\mathrm{a}},{ }^{\circ} \mathrm{C}\right)$,

$I_{\text {temp }}=I_{\max } Q_{\mathrm{a}}^{\frac{T_{\mathrm{a}}-20}{10}}$. 
Table 2. Description of fluxes used in mass balance equations.

\begin{tabular}{|c|c|c|}
\hline Flux & Units & Description \\
\hline$a_{\text {budC } 2 \text { leaf }}$ & $\mathrm{gC} \mathrm{m}^{-2} \mathrm{day}^{-1}$ & allocation from bud $\mathrm{C}$ pool to leaf $\mathrm{C}$ \\
\hline$a_{\text {woodC }}$ & $\mathrm{gC} \mathrm{m}^{-2} \mathrm{day}^{-1}$ & allocation from labile $\mathrm{C}$ to wood $\mathrm{C}$ \\
\hline$a_{\text {rootC }}$ & $\mathrm{gC} \mathrm{m}^{-2}$ day $^{-1}$ & allocation from labile $\mathrm{C}$ to wood $\mathrm{C}$ \\
\hline$a_{\text {budC_2Ramain }}$ & $\mathrm{gC} \mathrm{m}^{-2}$ day $^{-1}$ & $\begin{array}{l}\text { allocation of bud } \mathrm{C} \text { to maintenance respiration pool when maintain respiration pool reaches } \\
\text { zero; represents forgoing future leaf } \mathrm{C} \text { to prevent carbon starvation }\end{array}$ \\
\hline$a_{\text {budC }}$ & $\mathrm{gC} \mathrm{m}^{-2} \mathrm{day}^{-1}$ & allocation of labile $\mathrm{C}$ to bud $\mathrm{C}$; a fraction of the potential maximum leaf $\mathrm{C}$ \\
\hline$a_{\text {Ramain }}$ & $\mathrm{gC} \mathrm{m}^{-2}$ day $^{-1}$ & $\begin{array}{l}\text { allocation of labile } \mathrm{C} \text { to future maintenance respiration; helps prevent carbon starvation during } \\
\text { periods of negative NPP }\end{array}$ \\
\hline$a_{\text {budN_2leaf }}$ & $\mathrm{gN} \mathrm{m}^{-2}$ day $^{-1}$ & allocation from bud $\mathrm{N}$ pool to leaf $\mathrm{C}$; bud $\mathrm{N}$ is set in previous year \\
\hline$a_{\text {budN_2Ramain }}$ & $\mathrm{gN} \mathrm{m}^{-2}$ day $^{-1}$ & 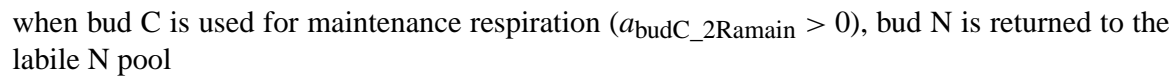 \\
\hline$a_{\text {budN }}$ & $\mathrm{gN} \mathrm{m}^{-2}$ day $^{-1}$ & $\begin{array}{l}\text { allocation of labile } \mathrm{N} \text { to bud } \mathrm{N} \text {; in seasonal environments it occurs in year prior to being dis- } \\
\text { played as leaf } \mathrm{N}\end{array}$ \\
\hline GPP & $\mathrm{gC} \mathrm{m}^{-2}$ day $^{-1}$ & photosynthesis; based on ACM model (see text for description) \\
\hline$L_{\mathrm{DON}}$ & $\mathrm{gN} \mathrm{m}^{-2}$ day $^{-1}$ & production and leaching of dissolved organic $\mathrm{N}$ \\
\hline$L_{\mathrm{NO}_{3}}$ & $\mathrm{gN} \mathrm{m}^{-2}$ day $^{-1}$ & leaching of $\mathrm{NO}_{3}^{-}$ \\
\hline $\mathrm{Ndep}_{\mathrm{NH}_{4}}$ & $\mathrm{gN} \mathrm{m}^{-2}$ day $^{-1}$ & input of $\mathrm{N}$ deposition to $\mathrm{NH}_{4}^{+}$pool \\
\hline & $\mathrm{gN} \mathrm{m}^{-2}$ day $^{-1}$ & nitrification of $\mathrm{NH}_{4}^{+}$to $\mathrm{NO}_{3}^{-}$ \\
\hline $\mathrm{N}_{\mathrm{depNO}_{3}}$ & $\mathrm{gN} \mathrm{m}^{-2}$ day $^{-1}$ & input of $\mathrm{N}$ deposition to $\mathrm{NO}_{3}^{-}$pool \\
\hline Ragrow & $\mathrm{gC} \mathrm{m}^{-2}$ day $^{-1}$ & $\begin{array}{l}\text { growth respiration that occurs when tissue is allocated; a constant fraction of carbon allocated } \\
\text { to tissue }\end{array}$ \\
\hline $\mathrm{Ra}_{\text {excess }}$ & $\mathrm{gC} \mathrm{m}^{-2}$ day $^{-1}$ & respiration that occurs when labile $\mathrm{C}$ exceeds a maximum labile $\mathrm{C}$ store; used for $\mathrm{N}$ fixation \\
\hline $\mathrm{Ra}_{\text {main }}$ & $\mathrm{gC} \mathrm{m}^{-2}$ day $^{-1}$ & respiration of living tissues; a function of $\mathrm{N}$ content and temperature \\
\hline$t_{\mathrm{CWDC}}$ & $\mathrm{gN} \mathrm{m}^{-2}$ day $^{-1}$ & turnover of coarse woody debris $\mathrm{C}$ into the litter $\mathrm{C}$ pool \\
\hline$t_{\text {leafC }}$ & $\mathrm{gC} \mathrm{m}^{-2} \mathrm{day}^{-1}$ & turnover of leaf $\mathrm{C}$ to litter $\mathrm{C}$; constant over year in humid tropics; seasonal otherwise \\
\hline$t_{\text {litterC soil }}$ & $\mathrm{gN} \mathrm{m}^{-2}$ day $^{-1}$ & turnover of litter $\mathrm{C}$ pool to soil $\mathrm{C}$ pool \\
\hline$t_{\text {litterC_atm }}$ & $\mathrm{gN} \mathrm{m}^{-2}$ day $^{-1}$ & turnover of litter $\mathrm{C}$ pool released as heterotrophic respiration \\
\hline$t_{\text {rootC }}$ & $\mathrm{gC} \mathrm{m}^{-2} \mathrm{day}^{-1}$ & turnover of root $\mathrm{C}$ to litter $\mathrm{C}$ pool; occurs throughout year \\
\hline$t_{\text {Soil_atm }}$ & $\mathrm{gN} \mathrm{m}^{-2}$ day $^{-1}$ & turnover of soil C released as heterotrophic respiration \\
\hline$t_{\mathrm{woodC}}$ & $\mathrm{gC} \mathrm{m}^{-2} \mathrm{day}^{-1}$ & turnover of wood C to CWDC pool; occurs throughout year \\
\hline$t_{\mathrm{CWDN}}$ & $\mathrm{gN} \mathrm{m}^{-2} \mathrm{day}^{-1}$ & turnover of coarse woody debris $\mathrm{C}$ to litter $\mathrm{C}$ pool \\
\hline$t_{\text {litterN }}$ & $\mathrm{gN} \mathrm{m}^{-2}$ day $^{-1}$ & turnover of litter $\mathrm{N}$ to soil $\mathrm{N}$ \\
\hline$t_{\text {leafN }}$ & $\mathrm{gN} \mathrm{m}^{-2}$ day $^{-1}$ & turnover of leaf $\mathrm{N}$ to litter $\mathrm{N}$; constant over year in humid tropics; seasonal otherwise \\
\hline$t_{\text {retransN }}$ & $\mathrm{gN} \mathrm{m}^{-2}$ day $^{-1}$ & reabsorption of $\mathrm{N}$ from leaves to labile $\mathrm{N}$ \\
\hline$a_{\text {woodN }}$ & $\mathrm{gN} \mathrm{m}^{-2}$ day $^{-1}$ & allocation from labile $\mathrm{N}$ to wood $\mathrm{N}$ \\
\hline$t_{\text {woodN }}$ & $\mathrm{gN} \mathrm{m}^{-2}$ day $^{-1}$ & turnover of wood N to CWDN pool; occurs throughout year \\
\hline$a_{\text {rootN }}$ & $\mathrm{gN} \mathrm{m}^{-2}$ day $^{-1}$ & allocation from labile $\mathrm{N}$ to wood $\mathrm{N}$ \\
\hline$t_{\text {rootN }}$ & $\mathrm{gN} \mathrm{m}^{-2}$ day $^{-1}$ & turnover of root $\mathrm{N}$ to litter $\mathrm{N}$ pool; occurs throughout year \\
\hline$t_{\text {soilN }}$ & $\mathrm{gN} \mathrm{m}^{-2}$ day $^{-1}$ & mineralization of soil $\mathrm{N}$ to $\mathrm{NH}_{4}^{+}$pool \\
\hline$U_{\mathrm{NH}_{4}}$ & $\mathrm{gN} \mathrm{m}^{-2}$ day $^{-1}$ & uptake of $\mathrm{NH}_{4}^{+}$from mineral soil $\mathrm{NH}_{4}^{+}$; based on Williams and Yanai (1996) \\
\hline$U_{\mathrm{NO}_{3}}$ & $\mathrm{gN} \mathrm{m}^{-2}$ day $^{-1}$ & uptake of $\mathrm{NO}_{3}^{-}$from mineral soil $\mathrm{NO}_{3}^{-}$; based on Williams and Yanai (1996) \\
\hline$U_{\mathrm{Nfix}}$ & $\mathrm{gN} \mathrm{m}^{-2}$ day $^{-1}$ & fixation of $\mathrm{N}$ from $\mathrm{N}_{2}$; function of Raexcess flux, temperature, $\mathrm{N}$ demand, and $\mathrm{C}$ cost. \\
\hline$U_{\mathrm{NH}_{4} \text { immob }}$ & $\mathrm{gN} \mathrm{m}^{-2}$ day $^{-1}$ & immobilization of $\mathrm{NH}_{4}^{+}$to soil $\mathrm{N}$ associated with the turnover of litter $\mathrm{C}$ and $\mathrm{N}$ \\
\hline$U_{\mathrm{NO}_{3} \text { immob }}$ & $\mathrm{gN} \mathrm{m}^{-2}$ day $^{-1}$ & immobilization of $\mathrm{NO}_{3}^{-}$to soil $\mathrm{N}$ associated with the turnover of litter $\mathrm{C}$ and $\mathrm{N}$ \\
\hline
\end{tabular}

The dimension factor $(\delta)$ linked to root structure is as follows:

$\delta=\frac{2}{2-\gamma} \frac{\left(\left(\frac{r_{x}}{r_{\text {radius }}}\right)^{2-\gamma}-1\right)}{\left(\left(\frac{r_{x}}{r_{\text {radius }}}\right)^{2}-1\right)}$.
An additional factor $(\gamma)$ is related to diffusion coefficients $(D)$ and buffering $(\beta)$ specific to the solute type:

$\gamma=\frac{r_{\text {radius }} v_{0}}{\beta_{\mathrm{NH}_{4}} D_{\mathrm{NH}_{4}}}$.

The parameters in Eq. (18) are adjusted according to whether $\mathrm{NO}_{3}^{-}$or $\mathrm{NH}_{4}^{+}$uptake is being determined. 
Table 3. Photosynthesis parameters $\left(\mathrm{acm}_{1-11}\right)$ for the aggregated canopy model (ACM), and fixed inputs (final three values in the table), used to determined carbon fixation in ACONITE.

\begin{tabular}{|c|c|c|c|c|}
\hline Parameter & $\begin{array}{l}\text { Units } \\
\text { (for inputs) }\end{array}$ & Description & Value & Reference \\
\hline $\mathrm{acm}_{1} *$ & & nitrogen-use efficiency (NUE) parameter & 12.0 & Fox et al. (2009) \\
\hline $\operatorname{acm}_{2} *$ & & day length coefficient & 1.526 & Fox et al. (2009) \\
\hline $\mathrm{acm}_{3} *$ & & canopy $\mathrm{CO}_{2}$ compensation point & 4.22 & Fox et al. (2009) \\
\hline $\mathrm{acm}_{4} *$ & & canopy $\mathrm{CO}_{2}$ half-saturation point & 208.9 & Fox et al. (2009) \\
\hline $\mathrm{acm}_{5} *$ & & day length scalar intercept & 0.0453 & Fox et al. (2009) \\
\hline $\operatorname{acm}_{6} *$ & & hydraulic coefficient & 0.378 & Fox et al. (2009) \\
\hline $\mathrm{acm}_{7} *$ & & maximum canopy quantum yield & 7.19 & Fox et al. (2009) \\
\hline $\mathrm{acm}_{8} *$ & & temperature coefficient & 0.011 & Fox et al. (2009) \\
\hline acm9* & & LAI-canopy quantum yield coefficient & 2.10 & Fox et al. (2009) \\
\hline $\operatorname{acm}_{10} *$ & & water potential constant & 0.79 & Fox et al. (2009) \\
\hline \multirow[t]{3}{*}{$\mathrm{acm}_{11}$} & & half-saturation of LAI-N $\mathrm{N}_{\text {leaf }}$ relationship & $\mathrm{T}: 0.05$ & \\
\hline & & & E: 0.05 & \\
\hline & & & $\mathrm{D}: 0.5$ & \\
\hline \multirow[t]{3}{*}{ lca* } & $\mathrm{gC} \mathrm{m}^{-2}$ & leaf $\mathrm{C}$ per area & $\mathrm{T}: 53$ & Kattge et al. (2011) \\
\hline & & & E: 100 & \\
\hline & & & D: 32 & \\
\hline$R_{\text {tot }}{ }^{*}$ & $\mathrm{MPa} \mathrm{m}^{2} \mathrm{~s} \mathrm{mmol}^{-1}$ & total plant-soil hydraulic resistance & Input $(0.1)$ & Fox et al. (2009) \\
\hline$\psi^{*}$ & $\mathrm{MPa}$ & maximum soil-leaf water potential difference & Input $(-2)$ & Fox et al. (2009) \\
\hline
\end{tabular}

* indicates that a parameter is also used in the DALEC-C model. T, tropical; E, temperate evergreen, D, temperate deciduous.

We estimate the rate of water inflow to the root surface $\left(v_{0}\right)$ as a proportion of GPP

$v_{0}=v \mathrm{GPP}$.

Adding a water cycle is necessary to more mechanistically calculate $v_{0}$, but the current approach captures the dependence of $\mathrm{N}$ uptake on transpiration-driven flow of water to the plant.

$\mathrm{N}$ uptake can be reduced $\left(X_{\mathrm{N}}\right)$ when the labile $\mathrm{N}$ pool is large relative to the size of the $\mathrm{N}$ store (Eq. 39).

$X_{\mathrm{N}}=\left\{\begin{array}{l}1-\left(\mathrm{N}_{\text {labile }} / \text { store }_{\operatorname{maxN}}\right), \mathrm{N}_{\text {labile }} \leq \text { store }_{\operatorname{maxN}} \\ 0, \quad \mathrm{~N}_{\text {labile }}>\text { store }_{\operatorname{maxN}} .\end{array}\right.$

\subsubsection{Plant allocation}

Allocation only occurs on days with a positive growth potential (growth potential $)$. Growth potential varies over the course of a year based on phenological relationships (Table 5; Supplement Fig. S1). Growth potential is $>0$ at the start of a temperate growing season, determined as when a growing degree day $\left(\mathrm{GDD}_{\text {start }}\right)$ threshold is exceeded. Growth potential equals 0 at the end of the season, defined by a day of year (DOY $\left.{ }_{\text {senesc }}\right)$. The existing code is suitable only for the Northern Hemisphere extra-tropics. (For equatorial regions growth potential is set to a positive value $(\theta)$ year-round. Further development is required before the model can be applied in dry tropics where temperature does not control phenology.)

growth $_{\text {potential }}=$
$\begin{cases}\theta, & \text { GDD } \geq \mathrm{GDD}_{\text {start }} \text { and DOY }<\text { DOY }_{\text {senesc }} \\ 0, & \text { otherwise }\end{cases}$

At each daily time step an instantaneous $\mathrm{C}$ return (Return leafCNInstant) is calculated to determine whether allocation occurs (Eq. 54). The instantaneous $\mathrm{C}$ return determines whether investing further $\mathrm{C}$ and $\mathrm{N}$ in foliage, at the current $\mathrm{C}: \mathrm{N}$ and environmental conditions, will result in a positive net uptake of $\mathrm{C}$ after accounting for gross photosynthesis, growth respiration, and maintenance respiration of additional leaf allocation. The marginal calculation is described in Sect. 2.1.9.

Based on the daily marginal returns (Return leafCNInstant $_{\text {), }}$ a decision tree is employed to determine allocation patterns from the available labile $\mathrm{C}$ pool $\left(\mathrm{C}_{\mathrm{avail}}=\right.$ growth $_{\text {potential }}$. $\mathrm{C}_{\text {labile}}$; Supplement Fig. S1).

1. If outside the growth period ( growth potential $=0$ ), $\mathrm{C}_{\text {labile }}$ is used to fill (via allocation flux $a_{\text {labileRamain }}$ ) the maintenance respiration pool $\left(C_{\text {labile }_{\mathrm{Ra}}}\right)$ up to its maximum value (Store $\mathrm{RaC}_{\mathrm{C}}$; Eq. 37); this ensures the vegetation has the required reserves to meet metabolic demand during winter.

2. If three tests (growth $_{\text {potential }}>0$, Return $_{\text {leafCNInstant }}>0$, and leaf $\mathrm{C}$ is less than its annual maximum (maxleafC; Sect. 2.1.7)), then bud $\mathrm{C}$ and bud $\mathrm{N}$ are converted into 
Table 4. Nitrogen uptake parameters, including units, nominal values and their sources.

\begin{tabular}{|c|c|c|c|c|}
\hline Parameter & Units & Description & Value & Reference \\
\hline$c_{\text {conc }} *$ & $\mathrm{gC} \mathrm{g}^{-1}$ & $\mathrm{C}:$ dry weight ratio & 0.5 & widely used \\
\hline$D_{\mathrm{NH}_{4}}$ & $\mathrm{~m}^{-2} \mathrm{~s}^{-1}$ & $\begin{array}{l}\text { effective diffusion coefficient of } \\
\text { the solute through the soil }\end{array}$ & $1 \times 10^{-11}$ & Williams and Yanai (1996) \\
\hline$D_{\mathrm{NO}_{3}}$ & $\mathrm{~m}^{-2} \mathrm{~s}^{-1}$ & $\begin{array}{l}\text { effective diffusion coefficient of } \\
\text { the solute through the soil }\end{array}$ & $2 \times 10^{-10}$ & Williams and Yanai (1996) \\
\hline$I_{\max }$ & $\mathrm{mmol} \mathrm{m}^{-2} \mathrm{~s}^{-1}$ & maximal nutrient influx rate & $4 \times 10^{-5}$ & Williams and Yanai (1996) \\
\hline$K_{m}$ & $\mathrm{mmol} \mathrm{m}^{-2} \mathrm{~s}^{-1}$ & $\begin{array}{l}\text { half saturation constant for up- } \\
\text { take }\end{array}$ & 15.0 & Williams and Yanai (1996) \\
\hline $\mathrm{Nfix}_{\text {pergC }}$ & $\mathrm{gN} \mathrm{gC}^{-1}$ & cost of $\mathrm{N}$ fixation & 0.11 & Gutschick (1981) \\
\hline$r_{\text {radius }}$ & $\mathrm{m}$ & radius of fine root & $5 \times 10^{-4}$ & $\begin{array}{l}\text { Fahey et al. (2005) definition of fine } \\
\text { root }\end{array}$ \\
\hline$r_{\text {depth }}$ & $\mathrm{m}$ & depth of soil explored by roots & varies by site & \\
\hline$r_{\text {density }}$ & $\mathrm{g} \mathrm{m}^{-3}$ & density of root mass & 175000 & Comas and Eissenstat (2004) \\
\hline$v$ & $\mathrm{~ms}^{-1}\left(\mathrm{gC} \mathrm{m}^{-2} \mathrm{day}^{-1}\right)^{-1}$ & $\begin{array}{l}\text { inward radial velocity of water } \\
\text { at the root surface per unit of } \\
\text { daily photosynthesis }\end{array}$ & $1 \times 10^{-9}$ & $\begin{array}{l}\text { value in Williams and } \\
\text { Yanai (1996); scaled by daily GPP }\end{array}$ \\
\hline$\beta_{\mathrm{NH}_{4}}$ & Unitless & soil buffer power $\left(\mathrm{NH}_{4}\right)$ & 10.0 & Williams and Yanai (1996) \\
\hline$\beta_{\mathrm{NO}_{3}}$ & Unitless & soil buffer power $\left(\mathrm{NO}_{3}\right)$ & 0.5 & Williams and Yanai (1996) \\
\hline
\end{tabular}

* indicates that a parameter is also used in the DALEC-C model.

foliar $\mathrm{C}$ and $\mathrm{N}$, at the target leaf $\mathrm{C}: \mathrm{N}$ (Sect. 2.1.7). $\mathrm{C}_{\text {avail }}$ is then allocated to buds, up to an amount (a proportion of maxleafC; leafC_2_bud_prop) that will allow the maximum leaf area to be reached. Allocation of $\mathrm{C}_{\mathrm{avai}}$ is limited to ensure buds have the target leaf $\mathrm{C}: \mathrm{N}$. For $\mathrm{C}$ allocation to buds, a requisite amount of $\mathrm{C}$ is also allocated to the growth respiration flux (Eq. 32). When foliar $\mathrm{C}$ is allocated, an associated allocation of wood must occur during the year to support the new foliage (parameter min_leaf_2_wood). A variable (wood_requirement) is incremented to track the need for wood; wood_requirement increases with foliage allocation and decreases with wood allocation.

3. If Return leafCNInstant $<0$ or the maxleafC has been attained, $\mathrm{C}$ and $\mathrm{N}$ are allocated to buds for future growth periods, and $\mathrm{C}$ is allocated to fill the maintenance respiration pool to its maximum size $\left(\right.$ Store $\left._{\mathrm{RaC}}\right)$. The remaining $\mathrm{C}_{\mathrm{avai}}$ and $\mathrm{N}_{\text {labile }}$ are used to pay down the wood requirement (wood_requirement), limited by the size of the labile pools and the need to construct wood at a fixed $\mathrm{C}: \mathrm{N}$. After wood allocation the remaining $\mathrm{C}_{\text {avail }}$ and $\mathrm{N}_{\text {labile }}$ are allocated at a fixed $\mathrm{C}: \mathrm{N}$ to grow fine roots up to a maximum root $\mathrm{C}$ (maxrootC; Sect. 2.1.7). Once the requirements for buds, maintenance respiration, wood and fine roots are met, then the final allocation decision depends on whether the labile $\mathrm{C}$ store has reached its maximum. If the $\mathrm{C}_{\text {labile }}$ has not reached capacity (Store $\operatorname{maxC}_{\text {C }}$ ), then $\mathrm{C}_{\text {labile }}$ is allowed to accumulate. If the store is full, then remaining $\mathrm{C}$ is allocated to wood, dependent on $\mathrm{N}$ availability. If $\mathrm{C}_{\text {labile }}>$ Store $_{\operatorname{maxC}}$ at this point, then the excess is allocated to excess autotrophic respiration $\left(\mathrm{Ra}_{\text {excessC }}\right)$, which leads to $\mathrm{N}$ fixation (see Eqs. 33 and 76).

\subsubsection{Plant tissue turnover}

The turnover of plant tissues $(t)$ is a function of tissue specific turnover rates $(\tau)$ and results in transfer of materials to specific litter pools (Fig. 1; Table 5). For foliage, turnover fluxes involve phenological cues, occurring only after a defined day in the year (DOY senesc $)$,

$t_{\text {leafC }}= \begin{cases}\mathrm{C}_{\text {leaf }} \tau_{\text {leaf }}, & \text { DOY }>\text { DOY } \\ 0, & \text { otherwise }\end{cases}$

In tropical environments without a distinct growing sea-

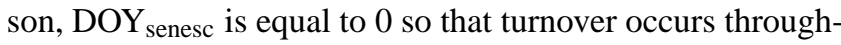
out the year.

For foliar N, a proportion of foliar turnover is retranslocated (Retrans_frac), so one fraction is transferred to litter pools:

$t_{\text {leafN }}=$

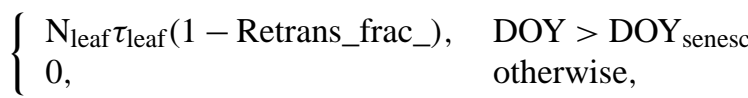

while the remainder is transferred to the labile plant $\mathrm{N}$ pool:

$t_{\text {retransN }}=$

$\begin{cases}\mathrm{N}_{\text {leaf }} \tau_{\text {leaf }} \text { Retrans_frac, } & \text { DOY }>\text { DOY } \\ 0, & \text { otherwise }\end{cases}$ 
Table 5. Plant allocation and turnover parameters, including units, nominal values and their sources. *indicates that a parameter is also used in the DALEC-C model.

\begin{tabular}{|c|c|c|c|c|}
\hline Parameter & Units & Description & Value & Reference \\
\hline DOYsenesc* & day & day of year that growth ends and leaf fall begins & $\begin{array}{l}\text { Varies } \\
\text { by } \\
\text { location }\end{array}$ & \\
\hline GDDStart* & day & growing degree day growth begins & 100 & Aber et al. (1997) \\
\hline growthresp & proportion & proportion of $\mathrm{C}$ allocation to tissue used for respiration & 0.28 & $\begin{array}{l}\text { Waring and } \\
\text { Schlesinger (1985) }\end{array}$ \\
\hline leafC_2_bud_prop & $\mathrm{g} \mathrm{bud}^{-1}$ max leaf $\mathrm{C}$ & proportion of maximum leaf $\mathrm{C}$ set as buds for next year & $\begin{array}{l}\text { T: } 0.5 \\
\text { E: } 0.1 \\
\text { D: } 0.5\end{array}$ & \\
\hline Min_leaf_2_wood & g wood C g leaf C & $\begin{array}{l}\text { minimum ratio of leaf } \mathrm{C} \text { production to allocated wood } \\
\mathrm{C} \text { production }\end{array}$ & 1.5 & White et al. (2000) \\
\hline Min_leaf_2_root & $\mathrm{g}_{\text {wood } \mathrm{Cg}^{-1} \text { leaf } \mathrm{C}}$ & minimum ratio of leaf $\mathrm{C}$ to $\operatorname{root} \mathrm{C}$ & 0.75 & \\
\hline Max_tissue_adjust & proportion day $^{-1}$ & $\begin{array}{l}\text { maximum potential annual proportional change in max- } \\
\text { imum leaf } \mathrm{C} \text { and } \operatorname{root} \mathrm{C}\end{array}$ & 0.1 & \\
\hline$Q_{\mathrm{a}}$ & unitless & $Q_{10}$ for maintenance respiration & 1.40 & Mahecha et al. (2010) \\
\hline Retrans_frac & proportion & proportion of leaf $\mathrm{N}$ retranslocated to labile $\mathrm{N}$ pool & 0.5 & widely used \\
\hline Ra_parm1 & $\mathrm{nmolg}^{-1} \mathrm{~s}^{-1}$ & $\begin{array}{l}\text { intercept coefficient for dark respiration vs. nitrogen } \\
\text { concentration }\end{array}$ & 0.833 & $\begin{array}{l}\text { Reich et al. (2008); all } \\
\text { plant groups and organs } \\
\text { combined }\end{array}$ \\
\hline Ra_parm2 & Unitless & $\begin{array}{l}\text { exponential coefficient for dark respiration vs. nitrogen } \\
\text { concentration }\end{array}$ & 1.268 & Reich et al. (2008) \\
\hline $\operatorname{rootCN}$ & $\mathrm{gC} \mathrm{gN}^{-1}$ & Root $\mathrm{C}: \mathrm{N}$ ratio & 50 & White et al. (2000) \\
\hline store_prop $\mathrm{RaC}$ & proportion & $\begin{array}{l}\text { proportion of wood and root } \mathrm{C} \text { that can be used for stor- } \\
\text { age of maintenance respiration }\end{array}$ & $\begin{array}{l}\text { T: } 0.01 \\
\text { E: } 0.05 \\
\text { D: } 0.01\end{array}$ & \\
\hline store_prop $\mathrm{N}$ & proportion & $\begin{array}{l}\text { proportion of wood and root } \mathrm{C} \text { that can be used for stor- } \\
\text { age of labile } \mathrm{N}\end{array}$ & 0.001 & \\
\hline store_propC & proportion & $\begin{array}{l}\text { proportion of wood and root } \mathrm{C} \text { that can be used for stor- } \\
\text { age of labile } \mathrm{C}\end{array}$ & 0.01 & \\
\hline woodCN & $\mathrm{gC} \mathrm{gN}^{-1}$ & wood $\mathrm{C}: \mathrm{N}$ ratio & 500 & White et al. (2000) \\
\hline$\theta$ & proportion & proportion of labile $\mathrm{C}$ available to use for growth & 0.07 & $\begin{array}{l}\text { approximates a } 2 \text {-week } \\
\text { turnover time for la- } \\
\text { bile pools; a balance be- } \\
\text { tween buffering the la- } \\
\text { bile pools and allowing } \\
\text { for responsive growth at } \\
\text { realistic time scales }\end{array}$ \\
\hline$\tau_{\text {leaf }} *$ & day $^{-1}$ & turnover of leaf $\mathrm{C}$ and $\mathrm{N}$ & $\begin{array}{l}\text { T: } 0.0019 \\
\text { E: } 0.00082 \\
\text { D: }>0.0027\end{array}$ & Kattge et al. (2011) \\
\hline$\tau_{\text {wood }} *$ & day $^{-1}$ & turnover of wood $\mathrm{C}$ and $\mathrm{N}$ & $\begin{array}{l}\mathrm{T}: 9 \times 10^{-6} \\
\mathrm{E}: 5 \times 10^{-5} \\
\mathrm{D}: 5 \times 10^{-5}\end{array}$ & $\begin{array}{l}\text { approximates a } 2 \% \\
\text { annual mortality rate } \\
\text { in temperate forest and } \\
3.3 \% \text { annual mortality } \\
\text { rate in tropical forest }\end{array}$ \\
\hline$\tau_{\text {root }} *$ & day $^{-1}$ & turnover of $\operatorname{root} \mathrm{C}$ and $\mathrm{N}$ & 0.002 & $\begin{array}{l}\text { based on McCormack } \\
\text { et al. (2013) }\end{array}$ \\
\hline$\tau_{\text {excessC }}$ & day $^{-1}$ & $\begin{array}{l}\text { turnover of labile } C \text { when pool exceeds the maximum } \\
\text { size of the labile } C \text { pool }\end{array}$ & 0.05 & \\
\hline
\end{tabular}

$\mathrm{T}$, tropical; E, temperate evergreen, D, temperate deciduous.

For wood and fine roots, turnover is a continual process without retranslocation:

$$
\begin{aligned}
t_{\text {woodC }} & =\mathrm{C}_{\text {wood }} \tau_{\text {wood }} \\
t_{\text {woodN }} & =\mathrm{N}_{\text {wood }} \tau_{\text {wood }} \\
t_{\text {rootC }} & =\mathrm{C}_{\text {root }} \tau_{\text {root }} \\
t_{\text {rootN }} & =\mathrm{N}_{\text {root }} \tau_{\text {root }} .
\end{aligned}
$$

\subsubsection{Plant respiration}

Maintenance respiration $\left(\mathrm{Ra}_{\text {main }}\right)$ can be related to the $\mathrm{N}$ content of plant tissues, and this observation has formed the basis of models (Cannell and Thornley, 2000). However, the precise relationships are uncertain, so two alternative approaches are explored here. 


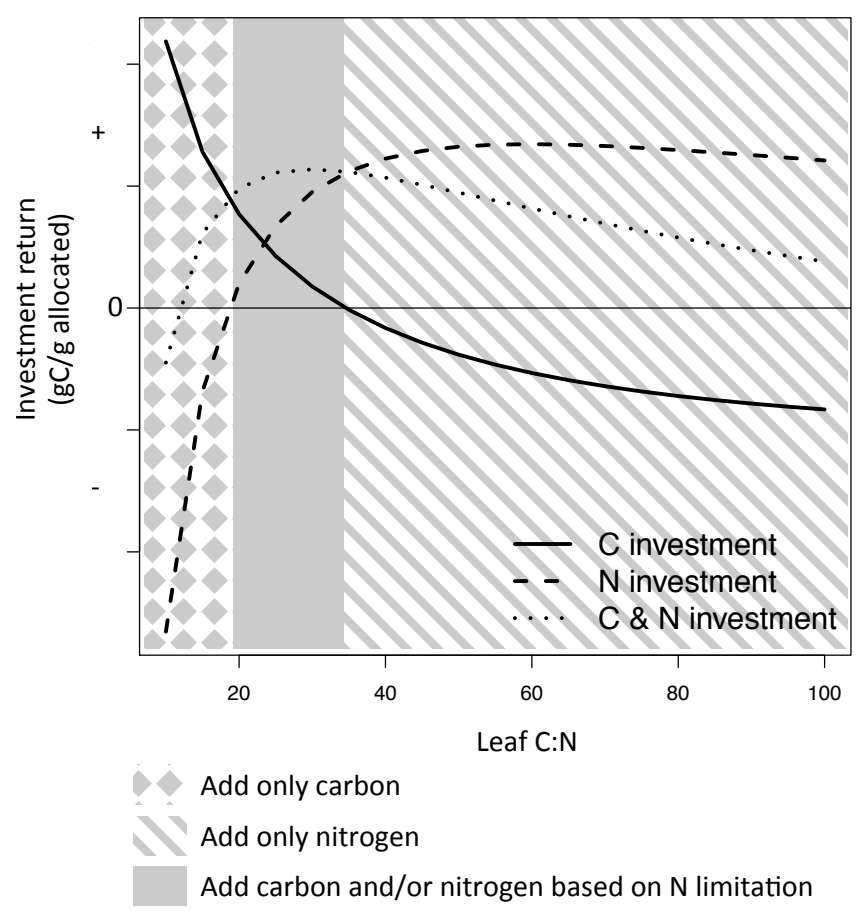

Figure 2. A schematic illustrating the adjustment of leaf $\mathrm{C}: \mathrm{N}$ for a given leaf area index using the marginal $\mathrm{C}$ returns on investment of leaf $\mathrm{C}$ and leaf $\mathrm{N}$. At low leaf $\mathrm{C}: \mathrm{N}$, leaf $\mathrm{N}$ has a negative return and leaf $\mathrm{C}$ has a positive return on investment that results in allocation to increase the leaf $\mathrm{C}: \mathrm{N}$ (diamond shading). At high leaf $\mathrm{C}: \mathrm{N}$, leaf $\mathrm{N}$ has a positive return and leaf $\mathrm{C}$ has a negative return that results in allocation to decrease the leaf $\mathrm{C}: \mathrm{N}$ (hashed shading). At intermediate leaf $\mathrm{C}: \mathrm{N}$, allocation of both leaf $\mathrm{C}$ and $\mathrm{N}$ are positive and allocation adjustments reflects where tissue growth is limited by $\mathrm{N}$ availability.

In the first option, the model builds on the observation from a global plant trait database that respiration is a nonlinear function (parameters: $\mathrm{Ra}_{\text {parm1 }}, \mathrm{Ra}_{\mathrm{parm} 2}$ ) of tissue $\mathrm{N}$ concentration (Reich et al., 2008). Tissue $\mathrm{N}$ concentration is determined as the $\mathrm{N}$ content ( $\mathrm{mmol}$ ) per $\mathrm{g}$ of tissue. Tissue mass is determined from tissue $\mathrm{C}$ content and a parameter, tissue $\mathrm{C}$ concentration, $\mathrm{gC} \mathrm{g}^{-1}$ tissue $\left(c_{\text {conc }}\right)$. The respiration is multiplied by a scalar $(S=86400)$ to convert respiration from per second to per day units. Respiration is only associated with the pools involved in uptake processes (so wood, bud and labile $\mathrm{N}$ does not affect the outcome). Because the equation is reported in Reich et al. (2008) as a log-log relationship, option 1 takes the following form (option 1):

$$
\begin{aligned}
& \mathrm{Ra}_{\text {main }}= \\
& \left(\left(\exp \left(\operatorname{Ra}_{\text {parm1 }}+\mathrm{Ra}_{\text {parm2 }} \log \left(\frac{\left(\frac{\mathrm{N}_{\text {leat }}}{14.0} 1000\right)}{\frac{\mathrm{C}_{\text {leaf }}}{c_{\text {conc }}}}\right)\right)\right) 1.2^{-8}\left(\frac{\mathrm{C}_{\text {leaf }}}{c_{\text {conc }}}\right) S\right) \\
& +\left(\left(\exp \left(\operatorname{Ra}_{\text {parm1 }}+\operatorname{Ra}_{\text {parm2 }} \log \left(\frac{\left(\frac{\left.\mathrm{N}_{\text {root }} 1000\right)}{14.0} 100\right)}{\frac{\mathrm{C}_{\text {root }}}{c_{\text {conc }}}}\right)\right) 1.2^{-8}\left(\frac{\mathrm{C}_{\text {root }}}{c_{\text {conc }}}\right) S\right) f(T) .\right.
\end{aligned}
$$

In the second option, the approach (Ryan, 1991) is based purely on a linear relationship (parameter: $\mathrm{Ra}_{\text {pergN }}$ ) between the total mass of foliar and fine root $\mathrm{N}$, modified by temperature. Again, respiration is only associated with the leaf and fine root pools (option 2):

$\mathrm{Ra}_{\text {main }}=\left(\mathrm{N}_{\text {leaf }}+\mathrm{N}_{\text {root }}\right) \operatorname{Ra}_{\text {per }_{g N}} f(T)$.

In both cases, the sensitivity of autotrophic respiration to average daily air temperature $\left(T_{\mathrm{a}}\right)$ is determined as follows:

$f(T)=Q_{\mathrm{a}}^{\frac{T_{\mathrm{a}}-20}{10}}$.

Plant maintenance respiration can occur each day and a buffer pool is required to avoid critical shortages during periods of low or zero photosynthesis. This labile respiration pool $\left(C_{\text {labile }}\right)$ is topped up from the $C_{\text {labile }}$ pool depending on whether a maximum pool size ( Store $_{\mathrm{RaC}}$ ) has been attained (Eq. 37).

Autotrophic respiration is also associated with the growth of new tissues (Ragrowth), whereby the allocation of $\mathrm{C}$ to a pool $X(X=$ bud $\mathrm{C}$, root $\mathrm{C}$ or wood $\mathrm{C})$ results in an additional fraction (growthresp) that is respired:

Ra $a_{\text {growth }}=a_{X}$ growthresp.

As described in Sect. 2.1.4, a fraction of labile C can be allocated (at a rate determined by parameter $\tau_{\text {excessC }}$ ) to excess autotrophic respiration $\left(\mathrm{Ra}_{\text {excess }}\right)$ to drive $\mathrm{N}$ fixation, if labile $\mathrm{C}$ remaining after other allocation $\left(\mathrm{C}_{\text {avail }}\right)$ exceeds the maximum storage capacity (store $\operatorname{maxC}_{\mathrm{C}}$ ), and growth is occurring

$\mathrm{Ra}_{\mathrm{excess}}=\left(\mathrm{C}_{\mathrm{avai}}-\right.$ store $\left._{\operatorname{maxC}}\right)$ growth $_{\text {potential }} \tau_{\text {excessC }}$.

During periods with high maintenance respiration fluxes but little production, plants can draw the storage pools of labile C (both $C_{\text {labile }}$ and $\mathrm{C}_{\text {labile }}$ ) down to zero. To avoid death when this occurs, plants are able to break down $\mathrm{C}$ allocated to buds for use in emergency maintenance respiration ( $\left.a_{\text {budc_2Ramain }}\right)$.

$a_{\text {budC_2Ramain }}=$
$-\max \left(\left(C_{\text {labileRa }}+C_{\text {labile }}+a_{\mathrm{Ra}_{\text {main }}}-\mathrm{Ra}_{\text {main }}\right), 0\right)$.

If $a_{\text {budC_2Ramain }}$ is positive, $\mathrm{N}$ is transferred from the $N_{\text {bud }}$ pool to the $\mathrm{N}_{\text {labile }}$ pool ( $\left.a_{\text {budN_2Ramain }}\right)$ based on the $\mathrm{C}: \mathrm{N}$ ratio of the bud pools.

\subsubsection{Annual adjustments to maximum plant tissue pool sizes}

At the end of each annual cycle, a series of tests are used to determine whether the vegetation should increase, hold, 


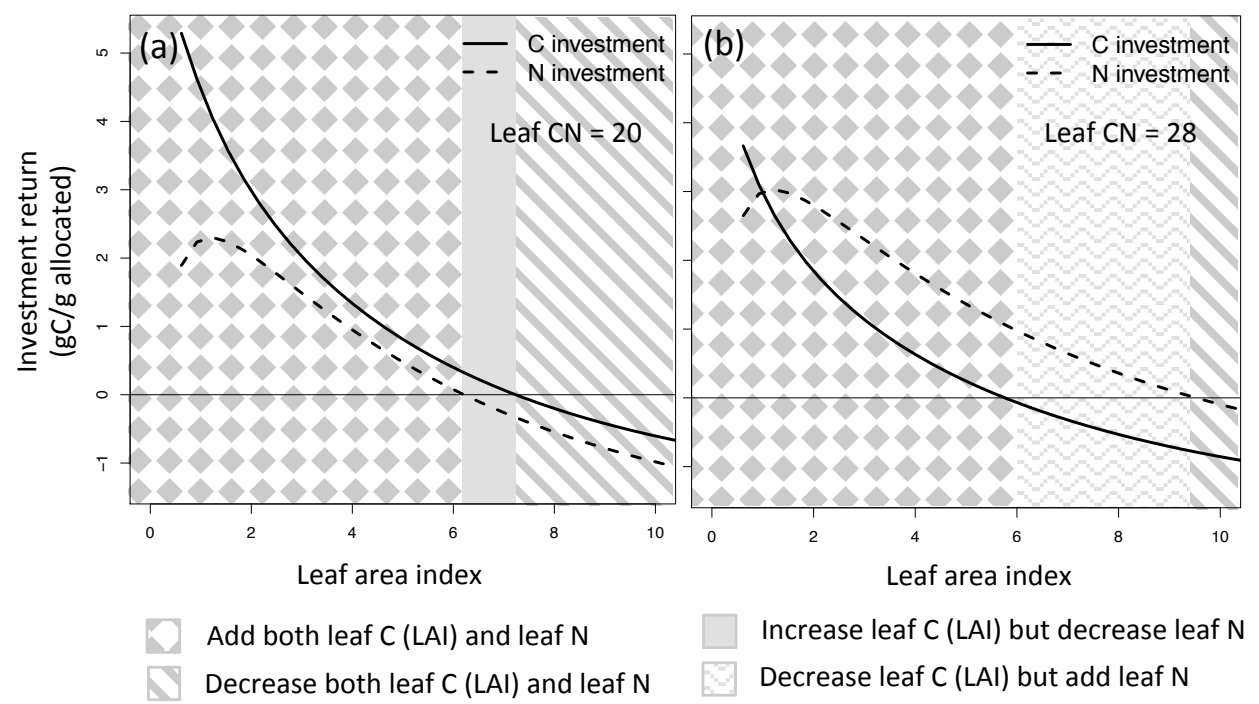

Figure 3. A schematic illustrating the simultaneous adjustment of leaf area index (LAI) and leaf $\mathrm{C}: \mathrm{N}$ (see legend above) based on the $\mathrm{C}$ return on marginal investment of leaf $\mathrm{C}$ (solid line) and leaf $\mathrm{N}$ (dashed line). Panel (a) shows the situation with a leaf $\mathrm{C}: \mathrm{N}$ of 20 and (b) shows the situation with a leaf $\mathrm{C}: \mathrm{N}$ of 28 , as examples. An optimal LAI and leaf $\mathrm{N}$ emerges from adjusting allocation so that marginal investment returns are zero for both leaf $\mathrm{C}$ and $\mathrm{N}$.

or decrease the maximum leaf $\mathrm{C}$ (maxleafC) and leaf $\mathrm{N}$ (maxleafN). The interaction of these adjustments results in changes to the target leaf $\mathrm{C}: \mathrm{N}$ (target leafCN$\left._{\mathrm{N}}\right)$ and maximum leaf $\mathrm{C}$ for the following year. Another set of tests determine adjustments to fine root $\mathrm{C}$ (maxrootC). Fine root $\mathrm{C}: \mathrm{N}$ (rootCN) is not adjusted.

Adjustments to maxleafN are based on: (1) whether the integrated annual marginal return on leaf $\mathrm{N}$ investment is positive for $\mathrm{C}$ balance (see Sect. 2.1.9, below), and (2) whether leaf $\mathrm{N}$ was deficient in the past year. Leaf $\mathrm{N}$ deficit is determined by checking if, on any day with potential growth during the past year, labile $\mathrm{N}$ stocks limited the allocation of $\mathrm{C}$ to leaf buds $\left(a_{\mathrm{budC}}\right)$ at the target $\mathrm{C}: \mathrm{N}$, by testing the inequality:

$\frac{a_{\text {budC }}}{\text { target }_{\text {leafCN }}}>\mathrm{N}_{\text {labile }}$ growth $_{\text {potential }}$.

The logic behind the three tests for changing maxleafN, with four outcomes, is as follows:

1. If the marginal return on $\mathrm{N}$ investment is negative, maxleafN should be decreased next year; the vegetation will improve its $\mathrm{C}$ balance by investing less $\mathrm{N}$ in foliage in this case.

2. If the marginal return on $\mathrm{N}$ investment is positive but last year's maxleafN was not attained, decrease maxleafN for the next year; in this case the vegetation was not able to attain the maximum given other allocation pressures and should be more conservative.

3. If the marginal return on $\mathrm{N}$ investment is positive, last year's maxleaf $\mathrm{N}$ was also attained, and no leaf $\mathrm{N}$ deficit occurred, then maxleafN is increased. The tests indicate that $\mathrm{N}$ is available for investment and this will result in positive $\mathrm{C}$ returns.

4. If the marginal return on $\mathrm{N}$ investment is positive, last year's maxleafN was attained, and a leaf $\mathrm{N}$ deficit occurred, maxleafN is held at the previous year maxleafN; the deficit signifies that $\mathrm{N}$ limitation is likely, even though $\mathrm{C}$ returns would be positive.

Adjustments to maxleafC are based on four related tests with five possible outcomes:

1. If in the previous year the maxleafC was attained, the wood allocation requirement (wood_requirement and maxrootC) was met, and the marginal return on $\mathrm{C}$ investment is positive, the maxleafC is increased; $\mathrm{C}$ is clearly in surplus and can be invested effectively.

2. If in the previous year the maxleafC was attained and the marginal return on $\mathrm{C}$ investment was positive but either the maxrootC was not attained or the wood allocation requirement (wood_requirement) was not met, maxleafC is decreased; in this case the supporting infrastructure for foliage was not attained and so the current maxleafC cannot be maintained.

3. If the marginal return on leaf $\mathrm{C}$ investment is negative, then maxleafC is decreased to improve the overall $\mathrm{C}$ balance.

4. If the maxleafC was not attained and no leaf $\mathrm{N}$ deficit occurred, maxleafC is reduced; in this case the vegetation is $\mathrm{C}$ limited. 
5. If the maxleafC was not attained but leaf $\mathrm{N}$ deficit occurred, maxleafC is held at the previous year maxleafC. In this case, maxleafC was not attained due to $\mathrm{N}$ limitation rather than $\mathrm{C}$ limitation. Based on the associated reduction to maxleafN described above, the target leafCN will increase.

For fine roots, there are five linked tests with five outcomes used to determine the maxrootC (fine $\operatorname{root} \mathrm{C}: \mathrm{N}(\operatorname{rootCN})$ is held constant in all cases).

1. If the current maxroot $C$ is less than the required root-toleaf ratio (parameter min_leaf_to_root), the maxrootC is increased.

2. If the maxrootC was not attained in the previous year and that maxrootC exceeds min_leaf_to_root, then maxrootC is decreased.

3. If maxrootC was reached and min_leaf_to_root is exceeded and either the marginal return on the investment of both $\mathrm{C}$ and $\mathrm{N}$ in roots (Return rootCN $_{\text {) }}$ is negative (see Sect. 2.1.9; Eq. 58) or the $\mathrm{N}$ return on $\mathrm{C}$ investment into $\mathrm{N}$ fixation exceeds the return on investment in roots (see Sect. 2.1.9; Eq. 57), maxrootC is decreased. This test shows that resources can be better allocated away from roots, to other tissues or to support $\mathrm{N}$ fixation.

4. If maxrootC was reached, $\mathrm{N}$ return on $\mathrm{C}$ investment in roots exceeds returns on investment in $\mathrm{N}$ fixation, the $\mathrm{N}$ return on $\mathrm{CN}$ investment in roots is positive, and leaf $\mathrm{N}$ was in deficit during the preceding year, maxrootC is increased. These tests show that $\mathrm{C}$ investment into roots is the most efficient means to relieve an $\mathrm{N}$ deficit by the foliage.

5. If maxrootC was reached, $\mathrm{N}$ return on $\mathrm{C}$ investment in roots exceeds returns on investment in $\mathrm{N}$ fixation and the $\mathrm{N}$ return on $\mathrm{CN}$ investment in roots is positive, but leaf $\mathrm{N}$ was not in deficit during the preceding year, the maxrootC is held at the previous year value. These tests indicate the current root $\mathrm{C}$ is close to optimal.

After the direction of adjustments to the maxleafC, maxleafN, and maxrootC are determined by the rules described above, the magnitude of the adjustment (tissue adjust $_{\text {) }}$ is based on a potential proportional rate of change (Max_tissue_adjust) scaled by the magnitude of the marginal return on leaf $C: N$ (see Sect. 2.1.9). Scaling the adjustment by the marginal return allows for larger adjustments when the plant is farther from the optimal tissue allocation. The tissue $_{\text {adjust }}$ for maxleafC, maxleafN, and maxrootC are based on

tissue $_{\text {adjust }}=$

$\min \left(\max \_t i s s u e \_a d j u s t,\left(\max \_t i s s u e \_a d j u s t\right.\right.$

$\left(\mid\right.$ Return $_{\text {leafC }}+$ Return $\left.\left._{\text {leafN }} \mid\right)\right)$.

\subsubsection{Adjustment to plant storage pools}

Plants store both $\mathrm{C}$ and $\mathrm{N}$ in labile pools $\left(\mathrm{C}_{\text {labile }}, \mathrm{N}_{\text {labile }}\right)$ prior to allocation, and $\mathrm{C}$ is also stored in a specific respiratory labile pool $\left(C_{\text {labile }}\right)$ to ensure metabolism through periods of low production. Each of these stores has a maximum size (Store $_{\operatorname{maxC}}$, Store maxN $_{\text {, Store }}$ RaC; Table 5), which is dependent on the magnitude of the root and wood tissue pools, which are the assumed locations of these stores, and specific parameters (store_prop ${ }_{X}$ ).

$$
\begin{aligned}
& \text { Store }_{\mathrm{RaC}}=\left(\mathrm{C}_{\mathrm{wood}}+\mathrm{C}_{\text {root }}\right) \text { store_prop } \\
& \text { Store }_{\operatorname{maxC}}=\left(\mathrm{C}_{\mathrm{wood}}+\mathrm{C}_{\text {root }}\right) \text { store_prop } \\
& \text { Store }_{\operatorname{maxN}}=\left(\mathrm{C}_{\mathrm{wood}}+\mathrm{C}_{\text {root }}\right) \text { store_prop } \\
& \text { Sto }_{\mathrm{N}} .
\end{aligned}
$$

\subsubsection{Marginal calculations for plants}

Marginal returns on investment are calculated each day, to inform daily allocation decisions (see Sect. 2.1.4), and also integrated over longer periods of time to adjust maximum structural pools (see Sect. 2.1.7) (see Table 5 for parameter values). Calculations are derived by forward finite difference (defined by the parameter $\operatorname{add}_{\mathrm{c}}$ ). The finite differences for $\mathrm{N}$ $\left(\operatorname{add}_{N_{\text {leaf }}}\right.$ and add $\left.{ }_{\text {Nroot }}\right)$ are determined from the fixed difference for $\mathrm{C}$ pools:

$$
\begin{aligned}
\operatorname{add}_{\text {Nleaf }} & =\operatorname{add}_{C} \frac{N_{\text {leaf }}}{C_{\text {leaf }}} \\
\operatorname{add}_{\text {Nroot }} & =\operatorname{add}_{C} \frac{1}{\text { rootCN }} .
\end{aligned}
$$

The marginal changes to photosynthesis from added leaf $\mathrm{C}$ $\left(\right.$ GPPreturn $\left._{\text {leafC }}\right)$, added leaf N (GPPreturn leafN $)$, added leaf $\mathrm{C}$ and $\mathrm{N}$ together (GPPreturn leafCN ), are determined using the GPP routine (Eq. 2) with arguments relating to tissue pools indicated within parentheses:

$$
\begin{aligned}
\operatorname{GPPreturn}_{\text {leafC }} & =\operatorname{GPP}\left(\mathrm{C}_{\text {leaf }}+\operatorname{add}_{\mathrm{C}}, \mathrm{N}_{\text {leaf }}\right) \\
& -\operatorname{GPP}\left(\mathrm{C}_{\text {leaf }}, \mathrm{N}_{\text {leaf }}\right) \\
\operatorname{GPPreturn}_{\text {leafN }} & =\operatorname{GPP}\left(\mathrm{C}_{\text {leaf }}, \mathrm{N}_{\text {leaf }}+\operatorname{add}_{\text {Nleaf }}\right) \\
& -\operatorname{GPP}\left(\mathrm{C}_{\text {leaf }}, \mathrm{N}_{\text {leaf }}\right) \\
\text { GPPreturn }_{\text {leafCN }} & =\operatorname{GPP}\left(\mathrm{C}_{\text {leaf }}+\operatorname{add}_{C}, \mathrm{~N}_{\text {leaf }}+\operatorname{add}_{\text {Nleaf }}\right) \\
& -\operatorname{GPP}\left(\mathrm{C}_{\text {leaf }}, \mathrm{N}_{\text {leaf }}\right) .
\end{aligned}
$$

The marginal change to maintenance respiration

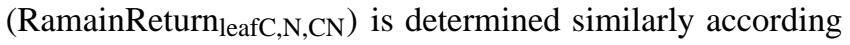
to $\mathrm{C}, \mathrm{N}$, or $\mathrm{C}$ and $\mathrm{N}$ changes:

$$
\begin{aligned}
\operatorname{RamainReturn}_{\text {leafC }} & =\operatorname{Ra}_{\text {main }}\left(\mathrm{C}_{\text {leaf }}+\operatorname{add}_{\mathrm{C}}, \mathrm{N}_{\text {leaf }}\right) \\
& -\operatorname{Ra}_{\text {main }}\left(\mathrm{C}_{\text {leaf }}, \mathrm{N}_{\text {leaf }}\right) \\
\operatorname{RamainReturn}_{\text {leafN }} & =\operatorname{Ra}_{\text {main }}\left(\mathrm{C}_{\text {leaf }}, \mathrm{N}_{\text {leaf }}+\operatorname{add}_{\mathrm{Nleaf}}\right) \\
& -\mathrm{Ra}_{\text {main }}\left(\mathrm{C}_{\text {leaf }}, \mathrm{N}_{\text {leaf }}\right) \\
\text { RamainReturn }_{\text {leafCN }} & =\operatorname{Ra}_{\text {main }}\left(\mathrm{C}_{\text {leaf }}+\operatorname{add}_{\mathrm{C}}, \mathrm{N}_{\text {leaf }}+\operatorname{add}_{\text {Nleaf }}\right) \\
& -\mathrm{Ra}_{\text {main }}\left(\mathrm{C}_{\text {leaf }}, \mathrm{N}_{\text {leaf }}\right) .
\end{aligned}
$$


The marginal change to growth respiration

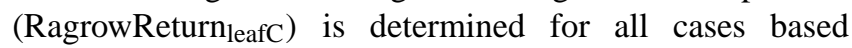
on added $\mathrm{C}$,

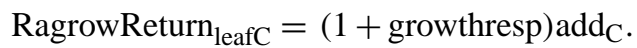

To determine the time-integrated cost of leaf and fine root production, the lifespan of these tissues is used to assess whether tissues can repay their costs over the period that the plant will retain the tissue. The period, or time horizon, differs whether it is used to inform daily allocation decisions (see Sect. 2.1.4) or for annual adjustments to the maximum structural pools (see Sect. 2.1.7).

In daily allocation for leaves, the time horizon is inversely proportional to the remaining days in the growing season $\left(\mathrm{DOY}_{\text {senesc }}-\mathrm{DOY}\right)$ for deciduous species and to the leaf turnover time $\left(\tau_{\text {leaf }}\right)$ for species with leaf lifespans $>12$ months (evergreen).

leaf $_{\text {horizonD }}= \begin{cases}1 /\left(\text { DOY }_{\text {senesc }}-\text { DOY }\right), & t_{\text {leaf }}>\frac{1}{365} \\ t_{\text {leaf }}, & t_{\text {leaf }} \leq \frac{1}{365}\end{cases}$

The leaf horizon used for the annual adjustment to the maximum size of the leaf pool is

leaf $_{\text {horizonA }}= \begin{cases}1.0, & t_{\text {leaf }}>\frac{1}{365} \\ 365 t_{\text {leaf }}, & t_{\text {leaf }} \leq \frac{1}{365}\end{cases}$

Since the returns are integrated over an annual cycle, vari-

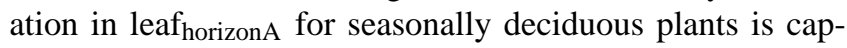
tured in the integrated returns. Therefore the annual return is not scaled by the leaf turnover rate. The leaf horizonA calculation assumes that all plants with leaf lifespans $<1.0$ year $\left(t_{\text {leaf }}>1 / 365\right)$ are seasonally deciduous.

The annual adjustment of the maximum size of the fine root pool uses

root $_{\text {horizon }}=365 t_{\text {root }}$.

The marginal returns on investments of $\mathrm{C}\left(\right.$ Return $\left._{\text {leafC }}\right)$ and of $\mathrm{N}$ (Return leafN) alone on $\mathrm{C}$ uptake (net production) can then be determined based on the sensitivity of annual production and maintenance respiration corrected for leaf lifespan, for growth respiration, and for the initial investment itself:

$\begin{aligned} \text { Return }_{\text {leafC }}= & \frac{\left(\text { GPPreturn }_{\text {leafC }}-\text { RamainReturn }_{\text {leafC }}\right)}{\text { leaf }_{\text {horizonA }}} \\ & - \text { RagrowReturn }_{\text {leafC }}-\text { add }_{\mathrm{C}} \\ \text { Return }_{\text {leafN }}= & \frac{\left(\text { GPPreturn }_{\text {leafN }}-\text { RamainReturn }_{\text {leafN }}\right)}{\text { leaf }_{\text {horizonA }}} .\end{aligned}$

The marginal return for daily allocation (Return leafCNInstant) is based on the $\mathrm{C}$ return on allocation of both leaf $\mathrm{C}$ and leaf $\mathrm{N}$ :

Return $_{\text {leafCNInstant }}=$

$\frac{\left(\text { GPPreturn }_{\text {leafCN }}-\text { RamainReturn }_{\text {leafCN }}\right)}{\text { leaf }_{\text {horizonD }}}$

- RagrowReturn $_{\text {leafC }}-\operatorname{add}_{C}$
The marginal returns on $\mathrm{N}$ uptake (UReturn ${ }_{X}$ ) are calculated similarly, using the uptake equation (Eq. 10) modified for root parameters (arguments are shown in parentheses):

$$
\begin{aligned}
U \text { return }_{\text {rootC }} & =U_{\mathrm{NH}_{4}}\left(\mathrm{C}_{\text {root }}+\operatorname{add}_{\mathrm{C}}, \mathrm{N}_{\text {root }}\right) \\
& +U_{\mathrm{NO}_{3}}\left(\mathrm{C}_{\text {root }}+\operatorname{add}_{\mathrm{C}}, \mathrm{N}_{\text {root }}\right) \\
& -U_{\mathrm{NH}_{4}}\left(\mathrm{C}_{\text {root }}, \mathrm{N}_{\text {root }}\right) \\
& -U_{\mathrm{NO}_{3}}\left(\mathrm{C}_{\text {root }}, \mathrm{N}_{\text {root }}\right) \\
U \text { return }_{\text {rootCN }} & =U_{\mathrm{NH}_{4}}\left(\mathrm{C}_{\text {root }}+\operatorname{add}_{C}, \mathrm{~N}_{\text {root }}+\operatorname{add}_{\text {Nroot }}\right) \\
& +U_{\mathrm{NO}_{3}}\left(\mathrm{C}_{\text {root }}+\operatorname{add}_{\mathrm{C}}, \mathrm{N}_{\text {root }}+\operatorname{add}_{\text {Nroot }}\right) \\
& -U_{\mathrm{NH}_{4}}\left(\mathrm{C}_{\text {root }}, \mathrm{N}_{\text {root }}\right) \\
& -U_{\mathrm{NO}_{3}}\left(\mathrm{C}_{\text {root }}, \mathrm{N}_{\text {root }}\right) .
\end{aligned}
$$

The uptake return $\left(\right.$ Return $\left._{\text {rootC }}\right)$ is then adjusted for root lifespan:

Return $_{\text {rootC }}=\frac{U \text { return }_{\text {rootC }}}{\text { root }_{\text {horizon }}}$.

For the $\mathrm{CN}$ marginal (Return ${ }_{\text {rootCN }}$ ) the return must be adjusted for the $\mathrm{N}$ invested:

Return $_{\text {rootCN }}=\frac{U \text { return }_{\text {rootCN }}}{\text { root }_{\text {horizon }}}-\operatorname{add}_{\text {Nroot }}$

The return on $\mathrm{C}$ investment into $\mathrm{N}$ fixation (Return Raexcess $_{\text {) }}$ is determined from the parameterized $\mathrm{N}$ fixation return $\left(N_{\text {fixpergC }}\right)$ adjusted by $\mathrm{N}$ uptake down-regulation $\left(X_{\mathrm{N}}\right.$, Eq. 20) and temperature (Eq. 31):

Return $_{\text {Raexcess }}=\operatorname{add}_{\mathrm{C}} \mathrm{Nfix}_{\text {pergC }} X_{\mathrm{N}} f(T)$.

Data on the relationship between root $\mathrm{N}$ content and $\mathrm{N}$ uptake rates (matching the well-established relationship between $\mathrm{N}$ concentration and photosynthesis for leaves), is lacking, thus creating a challenge for calculating a return on investment of root $\mathrm{N}$ alone (Ureturn $\left.{ }_{\text {rootN }}\right)$. Therefore, the root $\mathrm{N}$ return is not used in ACONITE version 1.0.

\subsubsection{Soil processes}

A simple, 3-pool (CWD, litter, SOM) soil dynamics model based on Thornton and Rosenbloom (2005) is used in this version of ACONITE; other soil decomposition models can be used in future applications. Soil processes are affected by the average daily air temperature $\left(T_{\mathrm{a}}\right)$ based on a $Q_{10}$ relationship:

$g(T)=Q_{h}^{\frac{T_{\mathrm{a}}-20}{10}}$.

The turnover of coarse woody litter pools $\left(t_{\mathrm{CWDC}}\right.$ and $\left.t_{\text {CWDN }}\right)$ is purely a function of temperature and a first order rate constant, consistent with physical breakdown:

$t_{\mathrm{CWDC}}=C_{\mathrm{cwd}} \tau_{\mathrm{cwd}} g(T)$
$t_{\mathrm{CWDN}}=N_{\mathrm{cwd}} \tau_{\mathrm{cwd}} g(T)$. 
Table 6. Soil Parameters, including units, nominal values and their sources.

\begin{tabular}{|c|c|c|c|c|}
\hline Parameter & Units & Description & Value & Reference \\
\hline DON_leach_prop & proportion & proportion of soil $\mathrm{N}$ turnover lost through DON leaching & 0.0015 & \\
\hline leach_rate & day $^{-1}$ & $\mathrm{NO}_{3}$ leaching rate & 0.00001 & \\
\hline m_resp_frac & proportion & proportion of litter $\mathrm{C}$ turnover respired & 0.5 & typical value from Parton et al. (1993) \\
\hline nitr_rate & day $^{-1}$ & nitrification rate & 0.0001 & \\
\hline$Q_{\mathrm{h}}{ }^{*}$ & unitless & soil respiration $Q_{10}$ & 1.4 & Mahecha et al. (2010) \\
\hline SoilCN & $\mathrm{gC} \mathrm{g} \mathrm{N}^{-1}$ & soil $\mathrm{C}: \mathrm{N}$ ratio & 12.0 & Thornton and Rosenbloom (2005) \\
\hline$\tau_{\text {litter }}{ }^{*}$ & day $^{-1}$ & litter turnover rate & 0.029 & typical value from Parton et al. (1993) \\
\hline$\tau_{\mathrm{cwd}} *$ & day $^{-1}$ & coarse woody debris turnover rate & 0.001 & Thornton and Rosenbloom (2005) \\
\hline$\tau_{\text {soil }} *$ & day $^{-1}$ & soil turnover rate & $1 \times 10^{-4}$ & assumed 20 year residence time \\
\hline
\end{tabular}

* indicates that a parameter is also used in the DALEC-C model.

The potential turnover of litter C (Pot_t $\left.t_{\text {litterC_soilC }}\right)$ is another temperature dependent first order process, with fluxes to either soil $\mathrm{C}$

Pot_ $t_{\text {litterC_soilC }}=C_{\text {litter }} \tau_{\text {litter }} g(T)(1-$ m_resp_frac $)$

or to the atmosphere (Pot_t $\mathrm{t}_{\text {litterC_atm }}$ ), via mineralization, according to a fractionation parameter (m_resp_frac)

Pot_t $\mathrm{l}_{\text {litterC_atm }}=C_{\text {litter }} \tau_{\text {litter }} g(T)$ m_resp_frac.

Litter $\mathrm{N}$ turnover $\left(t_{\text {litterN }}\right)$ is a similar process:

$t_{\text {litterN }}=N_{\text {litter }} \tau_{\text {litter }} g(T)$.

Immobilization is the process whereby mineral $\mathrm{N}$ is incorporated into organic, soil $\mathrm{N}$ by microbial action. The potential total immobilization (total $\left.{ }_{i m m o b}\right)$ is determined from the Pot_t $t_{\text {litterC_soilC, }}$, the (fixed) soil $\mathrm{C}: \mathrm{N}$ (Soil $\mathrm{CN}_{\mathrm{C}}$ ) and the turnover of litter :

total $_{\text {immob }}=\left(\right.$ Pot $\_t_{\text {litterC_soilC }} /$ Soil $\left.{ }_{\mathrm{CN}}\right)-t_{\text {litterN }}$

if total ${ }_{\text {immob }}<0$, then $\mathrm{N}$ is mineralized in the form of $\mathrm{NH}_{4}^{+}$. If total ${ }_{\text {immob }}>0$, then immobilization uses $\mathrm{NH}_{4}^{+}\left(\mathrm{NH}_{4}\right.$ immob $)$ and $\mathrm{NO}_{3}^{-}\left(\mathrm{NO}_{3 \mathrm{immob}}\right)$ according to their relative proportions:

$\mathrm{NH}_{4 \text { immob }}=$

$\begin{cases}\left(\text { Pot_t } t_{\text {litterC_soilC }} / \text { Soil }_{\mathrm{CN}}\right)-t_{\text {litterN }}, & \text { total }_{\text {immob }}<0 \\ \frac{\mathrm{N}_{\mathrm{NH}_{4}}}{\mathrm{~N}_{\mathrm{NH}_{4}}+\mathrm{N}_{\mathrm{NO}_{3}}} \text { total }_{\text {immob }}, & \text { total }_{\text {immob }} \geq 0\end{cases}$

$\mathrm{NO}_{3 \text { immob }}=$

$\left\{\begin{array}{c}0, \quad \text { Pot_total_immob }<0 \\ \frac{\mathrm{N}_{\mathrm{NO}_{3}}}{\mathrm{~N}_{\mathrm{NH}_{4}}+\mathrm{N}_{\mathrm{NO}_{3}}} \text { total } \\ \text { immob }\end{array}\right.$

Both these immobilizations are limited in magnitude by the size of each mineral pool.

The actual turnover of litter $\mathrm{C}\left(t_{\text {litterC_soil }}\right.$ and $\left.t_{\text {litterC_atm }}\right)$ is now determined from the potential values (Pot_t $t_{\text {litterC_soilC }}$ ) adjusted by the ratio of actual to potential immobilizations:

$$
\begin{aligned}
t_{\text {litterC_soilC }} & =\text { Pot_t } \text { litterC_soilC }_{\text {N }} \frac{\mathrm{NH}_{4 \text { immob }}+\mathrm{NH}_{3 \text { immob }}}{\text { total }_{\text {immob }}} \\
t_{\text {litterC_atm }} & =\text { Pot_t } t_{\text {litterC_atm }} \frac{\mathrm{NH}_{4 \text { immob }}+\mathrm{NH}_{3 \text { immob }}}{\text { total }_{\text {immob }}}
\end{aligned}
$$

The turnover of soil $\mathrm{C}\left(t_{\text {soilC }}\right)$ is a temperature dependent first order process:

$t_{\text {soilC }}=C_{\text {soil }} \tau_{\text {soil }} g(T)$.

Soil $\mathrm{N}$ is lost to $\mathrm{N}$ mineralization $\left(t_{\text {soilN }} ; \mathrm{NH}_{4}^{+}\right.$production $)$

$t_{\text {soilN }}=N_{\text {soil }} \tau_{\text {soil }} g(T)(1-$ DON_leach_prop $)$

and a fraction (DON_leach_prop) is dissolved organic $\mathrm{N}$ loss $\left(L_{\mathrm{DON}}\right)$ :

$L_{\text {DON }}=N_{\text {soil }} \tau_{\text {soil }} g(T)$ DON_leach_prop.

This simple dissolved organic $\mathrm{N}$ loss parameterization is broadly designed to represent demand-independent $\mathrm{N}$ losses in ACONITE, whereby $\mathrm{N}$ is lost through a pathway that cannot be controlled by plant uptake and microbial immobilization (Vitousek et al., 2010). Such a pathway is necessary for simulating $\mathrm{N}$ limitation at steady-state when $\mathrm{N}$ fixation inputs are included (Menge, 2011).

Nitrification (nitr), the production of $\mathrm{NO}_{3}^{-}$from $\mathrm{NH}_{4}^{+}$, is another first order temperature dependent process that uses a turnover parameter ( nitr $\left._{\text {rate }}\right)$ :

$\operatorname{nitr}=N_{\mathrm{NH}_{4}} \operatorname{nitr}_{\text {ratio }} g(T)$.

Nitrate is leached $\left(L_{\mathrm{NO}_{3}}\right)$ at a fixed rate (leach_rate):

$L_{\mathrm{NO}_{3}}=N_{\mathrm{NO}_{3}}$ leach_rate.

The soil parameters are listed in Table 6.

\subsubsection{N fixation}

$\mathrm{N}$ fixation occurs if labile $\mathrm{C}$ exceeds its maximum store (i.e. high energy inputs) and the $\mathrm{N}_{\text {labile }}$, is less than Store $_{\operatorname{maxN}}$ (i.e. $\mathrm{N}$ demand is not met). $\mathrm{N}$ fixation $\left(N_{\mathrm{fix}}\right)$ is calculated as:

$N_{\text {fix }}=\mathrm{Ra}_{\text {excess }} \mathrm{Nfix}_{\text {pergC }} X_{\mathrm{N}} f(T)$,

where $\mathrm{Nfix}_{\text {pergC }}$ is the $\mathrm{C}$ cost for fixing $\mathrm{N}$ and $\mathrm{Ra} \mathrm{a}_{\text {excess }}$ is from Eq. (33). 
Table 7. Steady state values of key ecosystem parameters for the three test systems evaluated with ACONITE.

\begin{tabular}{lrrrrrrr}
\hline Plant functional type & LAI & $\begin{array}{r}\text { Total vegetation C } \\
\mathrm{g} \mathrm{C} \mathrm{m}^{-2}\end{array}$ & $\begin{array}{r}\mathrm{GPP} \\
\mathrm{g} \mathrm{C} \mathrm{m}^{-2} \mathrm{yr}^{-1}\end{array}$ & $\begin{array}{r}\mathrm{NPP} \\
\mathrm{g} \mathrm{C} \mathrm{m}^{-2} \mathrm{yr}^{-1}\end{array}$ & $\begin{array}{r}\text { Carbon use } \\
\text { efficiency }\end{array}$ & $\begin{array}{r}\text { Leaf } \\
\mathrm{C}: \mathrm{N}^{\mathrm{N}}\end{array}$ & $\begin{array}{r}\mathrm{N} \text { fixation } \\
\mathrm{g} \mathrm{N} \mathrm{m}^{-2} \mathrm{yr}^{-1}\end{array}$ \\
\hline Tropical & 5.9 & 31300 & 3130 & 1423 & 0.45 & 28 & 0.6 \\
Temperate deciduous & 6.3 & 18900 & 1320 & 674 & 0.51 & 22 & 0.01 \\
Temperate evergreen & 4.4 & 20800 & 1649 & 737 & 0.44 & 43 & 0.02 \\
\hline
\end{tabular}

\subsection{Model parameters}

Flux rates are determined by a set of parameters controlling photosynthesis (Table 3), nitrogen uptake (Table 4), plant allocation (Table 5), plant turnover (Table 5), calculation of marginal returns (Table 5), and soil dynamics (Table 6). Model parameters were derived from the literature, or estimated in some cases, with sources clearly indicated. A full sensitivity analysis of the parameter values was undertaken.

\subsection{Model experiments}

We first examined the dynamics of leaf $\mathrm{C}$ and $\mathrm{N}$ optimization using only the canopy model of ACONITE. The canopy model included the photosynthesis, respiration, and marginal calculations described above. First, we simulated marginal annual $\mathrm{C}$ returns for the allocation of leaf $\mathrm{C}$, leaf $\mathrm{N}$, and both leaf $\mathrm{C}$ and $\mathrm{N}$ together in temperate deciduous and evergreen forests for two specified values of LAI (deciduous: 4.0 and 6.3; evergreen: 4 and 5) to explore how optimal leaf $\mathrm{C}: \mathrm{N}$ varies with LAI. Second, we simulated marginal returns in temperate deciduous and evergreen forests for two different values of the $\mathrm{acm}_{11}$ parameter ( 0.05 and 0.5$)$, a parameter new to the ACM canopy model. We specifically explored the $\mathrm{acm}_{11}$ parameter because prior model analysis indicated that different values are required for deciduous and evergreen forests to ensure proper optimization of leaf $\mathrm{C}: \mathrm{N}$ ratios. Finally, we simulated marginal returns for the two alternative representations of autotrophic respiration. In Eq. (29), we describe a relationship between mass-based leaf respiration and mass-based leaf $\mathrm{N}$ concentration based on the $\log -\log$ relationships from a plant trait database reported in Reich et al. (2008). The equation and parameters used from Reich et al. (2008) are based on the most comprehensive analysis of leaf respiration to date. However, many ecosystem and Earth System models use a linear relationship between total $\mathrm{N}$ and mass-based respiration from Ryan (1991) to parameterize autotrophic respiration (Eq. 30). The Ryan (1991) relationship was based on 16 observations, compared to 2510 observations in Reich et al. (2008). Because the Ryan (1991) equation is widely used in ecosystem modeling, we explored the sensitivity of leaf $\mathrm{C}: \mathrm{N}$ optimization to the two alternative parameterization of autotrophic respiration. All simulations using the canopy model were run for 1 year using Harvard Forest climate data from 2002 to generate annual marginal returns on investment of leaf $\mathrm{C}$, leaf $\mathrm{N}$, and leaf $\mathrm{C}$ and $\mathrm{N}$ together ( $\mathrm{g} \mathrm{C} / \mathrm{g} \mathrm{C}$ or $\mathrm{N}$ or $\mathrm{CN}$ ).

Next, using the full ACONITE model, we performed three numerical experiments to analyze the qualitative functioning of the model using two different sets of climate forcing, one tropical and one temperate. For the temperate forcing, two separate simulations were performed using a deciduous forest (leaf lifespan $<1$ year) and evergreen forest (leaf lifespan $>1$ year). The model was run to steady state using a 2000 year simulation that cycled through climate data from 2002 at Harvard Forest (Munger and Wofsy, 1999), $42.5^{\circ} \mathrm{N}, 72.0^{\circ} \mathrm{W}$. Steady state was evaluated by testing the stationarity of $\mathrm{C}_{\text {soil }}$, the longest residence time pool. The tropical simulation paralleled the temperate simulation with tropical tree parameters and climate data from 1999 at Manaus (Kruijt et al., 2004), $2.6^{\circ} \mathrm{N}, 60.2^{\circ} \mathrm{W}$.

The three simulations evaluated the model capacity to resolve differences in seasonality of climate forcing and phenology. We examined the annual GPP, annual carbon use efficiency (CUE; ratio of NPP to GPP), foliar C: N, maximum annual LAI and compared to representative ecosystem data. Intra-annual patterns in LAI, GPP, net primary production (NPP), leaf $\mathrm{C}$ allocation, wood $\mathrm{C}$ allocation, and root $\mathrm{C}$ allocation at steady-state for the temperate deciduous and tropical forests are described in the Supplement (Fig. S2 in the Supplement).

\subsection{Sensitivity analysis}

A single factor sensitivity analysis was undertaken for each parameter. We increased each parameter by $10 \%$ and report the sensitivity metric ( $S: \%$ change in response variable per $\%$ increase in parameter value) of maximum annual LAI, annual GPP, annual NPP, CUE, foliar $\mathrm{C}: \mathrm{N}$ ratio, and annual $\mathrm{N}$ fixation at steady state. Positive (negative) values of $S$ indicate a positive (negative) correlation between the parameter and the response variable, where $S$ values greater (less) than one (negative one) are parameters with amplifying sensitivity. The sensitivity analysis was performed for a tropical forest, a deciduous temperate forest, and an evergreen temperate forest at the same sites described above. Parameters with $S$ metrics greater than or equal to 0.1 are listed in Table 8 . 
Table 8. Sensitivity metric $(S)$ of key state variables to parameters in ACONITE for three ecosystem types (T, E, D) . Only parameters with $|S| \geq 0.1$ are listed.

\begin{tabular}{|c|c|c|c|c|c|c|c|c|c|c|c|c|c|c|c|c|c|c|c|c|c|}
\hline \multirow[b]{2}{*}{ Parameter } & \multicolumn{3}{|c|}{ LAI } & \multicolumn{3}{|c|}{ Total Vegetation C } & \multicolumn{3}{|c|}{ GPP } & \multicolumn{3}{|c|}{ NPP } & \multicolumn{3}{|c|}{ CUE } & \multicolumn{3}{|c|}{ Leaf $\mathrm{C}: \mathrm{N}$} & \multicolumn{3}{|c|}{$\mathrm{N}$ fixation } \\
\hline & $\mathrm{T}$ & $\mathrm{E}$ & $\mathrm{D}$ & $\mathrm{T}$ & $\mathrm{E}$ & $\mathrm{D}$ & $\mathrm{T}$ & $\mathrm{E}$ & $\mathrm{D}$ & $\mathrm{T}$ & $\mathrm{E}$ & $\mathrm{D}$ & $\mathrm{T}$ & $\mathrm{E}$ & $\mathrm{D}$ & $\mathrm{T}$ & $\mathrm{E}$ & $\mathrm{D}$ & $\mathrm{T}$ & $\mathrm{E}$ & $\mathrm{D}$ \\
\hline $\mathrm{acm}_{1}$ & -0.1 & -0.2 & -0.2 & 0.8 & 0.8 & 1.1 & 0.3 & 0.2 & 0.3 & 0.6 & 0.4 & 0.5 & 0.3 & -0.1 & 0.3 & 0.1 & 0.3 & - & 0.6 & 2.3 & 8.4 \\
\hline $\mathrm{acm}_{2}$ & 0.5 & 0.4 & 0.6 & 1.5 & 1.5 & 1.6 & 1.0 & 0.8 & 1.0 & 1.2 & 1.1 & 1.2 & 0.2 & -0.1 & 0.2 & -0.1 & -0.1 & - & 1.2 & 3.5 & 8.1 \\
\hline $\mathrm{acm}_{4}$ & - & - & -0.1 & -0.4 & -0.5 & -0.5 & -0.2 & -0.1 & -0.3 & -0.3 & -0.3 & -0.3 & -0.1 & -0.1 & -0.1 & - & -0.1 & - & -0.3 & -1.3 & -3.9 \\
\hline $\mathrm{acm}_{5}$ & 0.1 & 0.1 & 0.1 & 0.4 & 0.3 & 0.3 & 0.2 & 0.2 & 0.2 & 0.3 & 0.2 & 0.2 & 0.1 & - & 0.1 & - & - & - & 0.3 & 0.8 & 1.9 \\
\hline $\mathrm{acm}_{7}$ & 0.4 & 0.2 & 0.4 & 0.9 & 0.7 & 0.6 & 0.7 & 0.5 & 0.5 & 0.7 & 0.5 & 0.5 & - & - & 0.1 & -0.2 & -0.2 & - & 0.7 & 1.6 & 1.7 \\
\hline $\mathrm{acm}_{8}$ & - & - & - & 0.3 & 0.2 & 0.3 & 0.1 & 0.1 & 0.1 & 0.2 & 0.1 & 0.1 & 0.1 & 0.1 & 0.1 & 0.1 & - & - & 0.2 & 0.6 & 2.4 \\
\hline $\mathrm{acm}_{9}$ & 0.2 & 0.2 & 0.1 & - & -0.1 & - & - & 0.1 & & - & - & - & - & - & - & 0.2 & 0.2 & - & - & -0.7 & -0.5 \\
\hline $\mathrm{acm}_{10}$ & 0.2 & 0.3 & 0.4 & 0.2 & 0.4 & 0.3 & 0.2 & 0.4 & 0.3 & 0.2 & 0.3 & 0.3 & - & - & - & - & -0.1 & - & 0.2 & 0.5 & 0.2 \\
\hline $\mathrm{acm}_{11}$ & 0.1 & 0.1 & 0.3 & -0.1 & -0.1 & -0.3 & - & 0.1 & -0.2 & - & - & -0.1 & - & - & - & 0.1 & 0.1 & 0.3 & - & -0.4 & -5.2 \\
\hline$c_{\mathrm{conc}}$ & - & - & - & -0.2 & -0.2 & -0.2 & -0.1 & - & -0.1 & -0.2 & -0.1 & -0.1 & -0.1 & 0.1 & -0.1 & 0.2 & 0.1 & 0.1 & -0.2 & 0.6 & 0.7 \\
\hline DON_leach_propg & - & - & - & - & - & - & - & - & - & - & - & - & - & - & - & - & - & - & 1.0 & - & 0.1 \\
\hline DOY $_{\text {Sensce }}$ & - & 0.2 & 0.6 & - & 1.3 & 1.4 & - & 0.7 & 1.1 & - & 0.9 & 1.1 & - & 0.1 & - & - & -0.1 & 0.5 & - & 2.4 & 5.4 \\
\hline GDDStart & - & - & - & - & - & -0.1 & - & - & - & - & - & - & - & -0.1 & - & - & - & - & - & 0.2 & -0.1 \\
\hline growthresp & -0.1 & -0.1 & -0.1 & -0.4 & -0.4 & -0.3 & -0.1 & - & - & -0.4 & -0.3 & -0.2 & -0.2 & 0.2 & -0.2 & - & -0.1 & - & -0.4 & -0.5 & -1.4 \\
\hline$I_{\max }$ & - & - & - & - & - & - & - & - & - & - & - & - & - & - & - & - & - & - & - & -1.3 & 2.1 \\
\hline$K_{m}$ & - & - & - & - & - & - & - & - & - & - & - & - & - & - & - & - & - & - & - & - & 0.1 \\
\hline lca & -0.6 & -0.5 & -0.7 & -0.2 & -0.3 & -0.3 & - & 0.1 & -0.1 & - & 0.1 & - & - & - & 0.1 & 0.4 & 0.4 & 0.4 & - & -1.9 & -6.3 \\
\hline leach_rate & - & - & - & - & - & - & - & - & - & - & - & - & - & - & - & - & - & - & & - & -0.1 \\
\hline Min_leaf_2_wood & 0.1 & 0.1 & 0.1 & 0.2 & 0.3 & 0.4 & 0.1 & 0.2 & 0.2 & 0.2 & 0.2 & 0.3 & 0.1 & - & 0.1 & - & - & - & 0.2 & -0.7 & -4.2 \\
\hline Min_leaf_2_root & - & 0.1 & 0.1 & -0.3 & -0.7 & -0.2 & - & 0.2 & 0.1 & -0.1 & - & - & -0.1 & -0.1 & -0.1 & - & - & - & -0.1 & -2.4 & -4.4 \\
\hline$m_{\text {_resp_frac }}$ & - & - & - & - & - & - & - & - & - & - & - & - & - & - & - & - & - & - & 1.0 & - & 0.1 \\
\hline Nfix $x_{\text {pergc }} g$ & - & - & - & - & - & - & - & - & - & - & - & - & - & - & - & - & - & - & - & 1.0 & 1.0 \\
\hline Qa & - & - & - & -0.4 & 0.6 & 0.3 & -0.1 & 0.1 & - & -0.3 & 0.3 & 0.2 & -0.2 & 0.1 & 0.3 & 0.4 & -0.5 & -0.2 & -0.4 & 1.4 & 2.5 \\
\hline Retrans_frac & - & - & - & - & - & - & - & - & - & - & - & - & - & - & - & - & - & - & - & - & -0.1 \\
\hline Ra_parm1 & _- & - & -0.1 & -0.6 & -0.7 & -0.4 & -0.1 & - & -0.2 & -0.5 & -0.4 & -0.3 & -0.3 & 0.2 & -0.3 & 0.5 & 0.4 & 0.4 & -0.5 & -1.9 & -3.4 \\
\hline Ra_parm2 & 1.0 & 0.9 & 0.4 & -0.2 & - & -0.1 & - & 0.2 & -0.1 & 0.2 & 0.4 & 0.1 & 0.2 & -0.2 & 0.3 & 1.6 & 1.1 & 1.2 & 0.1 & -1.6 & -4.5 \\
\hline$r_{\text {radius }}$ & - & - & - & - & - & - & - & - & - & - & - & - & - & - & - & - & - & - & - & 1.1 & 1.6 \\
\hline rootCN & _- & - & -0.1 & 0.3 & 0.4 & 0.2 & - & -0.1 & -0.1 & 0.2 & 0.2 & 0.1 & 0.2 & 0.1 & 0.3 & - & - & - & 0.2 & 0.5 & 1.6 \\
\hline$r_{\text {density }}$ & - & - & - & - & - & - & - & - & - & - & - & - & - & - & - & - & & & - & 1.1 & 1.6 \\
\hline$r_{\text {depth }}$ & - & - & - & - & - & - & - & - & - & - & - & - & - & - & - & - & - & - & - & - & 0.1 \\
\hline store_prop ${ }_{C}$ & 0.2 & 0.1 & -0.1 & 0.5 & 0.2 & 0.1 & 0.3 & 0.2 & 0.1 & 0.4 & 0.2 & - & 0.1 & -0.1 & 0.1 & - & & & 0.4 & 0.3 & 0.8 \\
\hline store_prop & - & - & - & - & - & - & - & - & - & - & - & - & - & - & - & - & & & - & 0.2 & 0.8 \\
\hline soilCN & - & - & - & - & - & - & - & - & - & - & - & - & - & - & - & - & - & - & -1.1 & - & -0.2 \\
\hline woodCN & - & - & - & - & - & - & - & - & - & - & - & - & - & - & - & - & - & - & - & -0.2 & -0.3 \\
\hline$\theta$ & 0.1 & 0.1 & - & 0.4 & 0.2 & 0.1 & 0.3 & 0.1 & - & 0.3 & 0.1 & - & 0.1 & - & 0.1 & - & - & - & 0.4 & 0.5 & - \\
\hline$\tau_{\lambda \text { eaf }}$ & -0.6 & -0.6 & - & - & 0.1 & - & -0.1 & - & - & - & - & - & - & - & 0.1 & -0.5 & -0.5 & - & - & - & -0.2 \\
\hline$\tau_{\text {wood }}$ & -0.1 & -0.1 & - & -1.6 & -1.3 & -1.1 & -0.3 & -0.1 & -0.1 & -0.4 & -0.2 & - & -0.1 & - & - & - & - & - & -0.4 & -0.5 & - \\
\hline$\tau_{\text {root }}$ & - & - & - & -0.1 & -0.3 & -0.1 & - & 0.1 & - & - & 0.1 & 0.1 & - & - & 0.1 & - & - & - & - & - & -0.5 \\
\hline$\tau_{\text {soil }}$ & - & - & - & - & - & - & - & - & - & - & - & - & - & - & - & - & & & & & -0.5 \\
\hline$\tau_{\text {excessC }}$ & - & - & - & - & - & - & - & - & - & - & - & - & - & - & - & - & - & - & -0.1 & 1.0 & 0.9 \\
\hline
\end{tabular}

\section{Results}

\subsection{Canopy model simulations investigating leaf $\mathrm{C}: \mathrm{N}$ ratio and LAI dynamics}

In the canopy-only experiment for a temperate deciduous forest, we found that the calculation of annual marginal yields of leaf $\mathrm{C}$ and $\mathrm{N}$ allowed for the optimization of leaf $\mathrm{C}: \mathrm{N}$ based on the leaf parameters (leaf lifespan, specific leaf area), the environmental conditions, and $\mathrm{N}$ status of the plant. Initial low leaf $\mathrm{C}: \mathrm{N}(<19)$ were linked to positive margins on $\mathrm{C}$ investment alone, and so led to the addition of leaf $\mathrm{C}$ only (and thus increasing leaf $\mathrm{C}: \mathrm{N})$. Initial high leaf $\mathrm{C}: \mathrm{N}(>35)$ were linked to positive margins on $\mathrm{N}$ investment, and so led to addition of leaf $\mathrm{N}$ only (thus decreasing leaf $\mathrm{C}: \mathrm{N}$ ). Intermediate initial leaf $\mathrm{C}: \mathrm{N}(19-35)$ had positive margins for both $\mathrm{C}$ and $\mathrm{N}$ investment, and so allow for a flexible leaf $\mathrm{C}: \mathrm{N}$ based on $\mathrm{N}$ status (Fig. 2).

As LAI varied, the range of flexible leaf $\mathrm{C}: \mathrm{N}$ was altered (Fig. 3). At low LAI, increasing both leaf $\mathrm{C}$ and leaf $\mathrm{N}$ had positive returns. As LAI increased with a low leaf $\mathrm{C}: \mathrm{N}$ (Fig. 3a), the marginal return on $\mathrm{N}$ investment went negative first; so the plant decreased allocation to $\mathrm{N}$, before decreasing allocation to leaf $\mathrm{C}$, resulting in increased leaf $\mathrm{C}: \mathrm{N}$ as the plant reaches the maximum LAI with a positive return on $\mathrm{C}$ (hashed shading). However, a large increase in leaf $\mathrm{C}: \mathrm{N}$ from 20 (a) to 28 (b) reduced the investment return on leaf $\mathrm{C}$ and increased the return on leaf $\mathrm{N}$ at a given LAI, resulting in a lower maximum LAI and lower leaf $\mathrm{C}: \mathrm{N}$. An optimal LAI and leaf $\mathrm{N}$ emerged from adjusting allocation so that marginal investment returns were zero for both leaf $\mathrm{C}$ and $\mathrm{N}$.

Successfully generating these leaf $\mathrm{C}: \mathrm{N}$ patterns (an increasing leaf $\mathrm{C}$ region, an increasing leaf $\mathrm{N}$ region, and a flexible region) for different parameterized leaf traits (lifespan, leaf mass per area) required a different value for the $\mathrm{acm}_{11}$ parameter used in calculating GPP for deciduous and evergreen forests (Fig. 4). Low values of the $\mathrm{acm}_{11}$ in deciduous forests led to an unrealistically low leaf $\mathrm{C}: \mathrm{N}$ and no flexible leaf $\mathrm{C}: \mathrm{N}$ region (Fig. 4a). In contrast, high values of the $\mathrm{acm}_{11}$ parameter applied to evergreen forests (Fig. 4d) did not yield a reasonable maximum leaf $\mathrm{C}: \mathrm{N}$. This parameter was introduced to reduce photosynthesis for canopies with LAI : $\mathrm{N}_{\text {leaf }}$ ratios that diverge from the optimum slope identified in field studies and ecophysiological modeling (Williams and Rastetter, 1999). Further work with ecophysiological modeling is required to generate a more effective representation of this effect in ACM, and to explore the relationship with other leaf traits. 
Successfully generating leaf $\mathrm{C}: \mathrm{N}$ patterns required for leaf $\mathrm{C}: \mathrm{N}$ optimization did not strongly depend on the parameterization of autotrophic respiration (Fig. 5). The widely used linear relationship between leaf $\mathrm{N}$ and respiration from Ryan (1991) generated a leaf $\mathrm{C}: \mathrm{N}$ that was similar to the non-linear relationship from Reich et al. (2008).

\subsection{Steady-state simulations with full ACONITE model across multiple biomes}

Steady-state simulations with the full ACONITE model, using the non-linear autotrophic respiration equation (Reich et al., 2008) and the deciduous and evergreen values for the $\mathrm{acm}_{11}$ parameter, had patterns in leaf $\mathrm{C}: \mathrm{N}$ patterns that compared well to patterns from the TRY plant trait database (Kattge et al., 2011). Comparing leaf $\mathrm{C}: \mathrm{N}$ among temperate deciduous, temperate evergreen, and tropical evergreen trees, both ACONITE and the TRY database found the following order (Table 7): temperate deciduous (ACONITE: 22; TRY: 23 ) < tropical evergreen trees (ACONITE: 28; TRY $30)<$ temperate evergreen (ACONITE: 43; TRY 41).

Steady-state values for LAI revealed closed canopies (LAI $\gg 1$ ) for each ecosystem, with a range of 4.4-6.3, and no clear climate effect (Table 7). Total vegetation C, GPP and NPP all decreased from the tropical simulation to the temperate simulation. CUE was larger in short-lifetime species (temperate deciduous) than longer-lifetime species (temperate evergreen and tropical evergreen). $\mathrm{N}$ fixation at steadystate decreased by an order of magnitude from the tropics to temperate forests. Within temperate forests, steady-state values for total vegetation $\mathrm{C}$, GPP, NPP, and N fixation were similar for both deciduous and evergreen forests.

\subsection{Parameter sensitivity analysis}

Leaf $\mathrm{C}: \mathrm{N}$ was most sensitive to the parameter (Ra_parm2) describing the slope of the $\log -\log$ relationship between $\mathrm{N}$ concentration and autotrophic respiration (Table 8). A steeper slope of the $\log -\log$ relationship increased leaf $\mathrm{C}: \mathrm{N}$ by a proportional amount that exceeded the proportional change in the parameter $(S=1.1-1.6)$. Leaf $\mathrm{C}: \mathrm{N}$ also increased with leaf-lifespan, which is governed by the leaf turnover parameter $\left(\tau_{\text {leaf }}\right)$ for the tropical and temperate evergreen forest and the date of leaf drop parameters (SensceStart) for the temperate deciduous forest. Leaf carbon per leaf area (lca) and Ra_parm2 also influenced the leaf $\mathrm{C}: \mathrm{N}$ ratio.

Similar to leaf $\mathrm{C}: \mathrm{N}$ ratio, LAI was most sensitive to the Ra_parm2 parameter, particularly tropical and temperate evergreen forests (Table 8 ) where the proportional sensitivity was $>1$. Other sensitive parameters for LAI were parameters that governed the leaf lifespan ( $\tau_{\text {leaf }}$ and SenceStart), specific leaf area (lca), and the photosynthesis relationship with day length $\left(\mathrm{acm}_{2}\right)$. Steeper slopes of the $\mathrm{N}$ vs. respiration relationship (Ra_parm2) resulted in larger LAI values, while increasing leaf-lifespan $\left(\tau_{\text {leaf }}\right.$ and SenceStart $)$ decreased the
LAI. LAI decreased with increased leaf carbon per leaf area (lca).

Total vegetation C stocks, GPP, and NPP were most sensitive to parameters that governed the total photosynthesis relationship with day length $\left(\mathrm{acm}_{2}\right)$ and growing season length (SenceStart). Additionally, total vegetation $\mathrm{C}$ was most sensitive to the rate of wood turnover $\left(\tau_{\text {wood }}\right)$. Sensitivities were similar across the three forest types, except for the low sensitivity to growing season length in the tropical forest, consistent with its lack of a seasonal cycle.

$\mathrm{N}$ fixation was sensitive to numerous parameters, indicating the strong coupling of $\mathrm{C}$ and $\mathrm{N}$ dynamics for this process. The strongest sensitivity was to the rate of photosynthesis $\left(\mathrm{acm}_{2}\right.$ : day length - GPP relationship). $\mathrm{N}$ fixation in temperate forests was sensitive to $\mathrm{N}$ uptake parameters ( $r_{\text {radius }}, I_{\max }$, and $r_{\text {density }}$ ) despite a lack sensitivity of LAI, total vegetation $\mathrm{C}$, GPP, NPP, and leaf $\mathrm{C}: \mathrm{N}$ to these $\mathrm{N}$ uptake parameters.

CUE was not strongly sensitive to any parameters $(|S| \leq$ 0.3). CUE is a complex outcome of $\mathrm{N}$ allocation, which determines both photosynthesis and autotrophic respiration; CUE sensitivity was greatest to photosynthetic parameters $\left(\mathrm{acm}_{1}, \mathrm{acm}_{2}\right)$ and to respiration parameters $\left(Q_{\mathrm{a}}, \mathrm{Ra}\right.$ _parm1, Ra_parm2, Ra_grow). There was also sensitivity to root $\mathrm{CN}$.

\section{Discussion}

Here we described and evaluated a simple model of terrestrial $\mathrm{C}$ and $\mathrm{N}$ dynamics that included prognostic leaf $\mathrm{C}: \mathrm{N}$, maximum LAI, $\mathrm{N}$ fixation, and plant $\mathrm{C}$ use efficiency. Most fundamentally, ACONITE was able to simulate steady-state C and $\mathrm{N}$ stocks and fluxes that are qualitatively consistent with biome level observations for a diverse set of environmental conditions, both temperate and tropical, and for deciduous and evergreen forests. ACONITE simulated these patterns in $\mathrm{C}$ and $\mathrm{N}$ dynamics using a minimal set of parameters based on marginal returns on investment, linked to a hypothesis of plant optimization.

The simulations presented in this study focused on capturing broad biome patterns in $\mathrm{C}$ and $\mathrm{N}$ cycling rather than site-specific dynamics. This is expressed by the use of plant trait parameters from a global database rather than site-level observations and the use of parameters for the canopy photosynthesis calculations from an analysis of deciduous and evergreen eddy-covariance towers in Europe using the DALEC model (Fox et al., 2009). Furthermore, we used a single year of climate data at each site to simulate the steady-state conditions rather than a site-specific climatology.

\subsection{Model evaluation}

A biome level evaluation suggests that ACONITE captures important patterns in leaf $\mathrm{C}: \mathrm{N}$ ratios, NPP, and $\mathrm{N}$ fixation. ACONITE simulated biome level patterns in leaf $\mathrm{C}: \mathrm{N}$ that matched observations from a global 


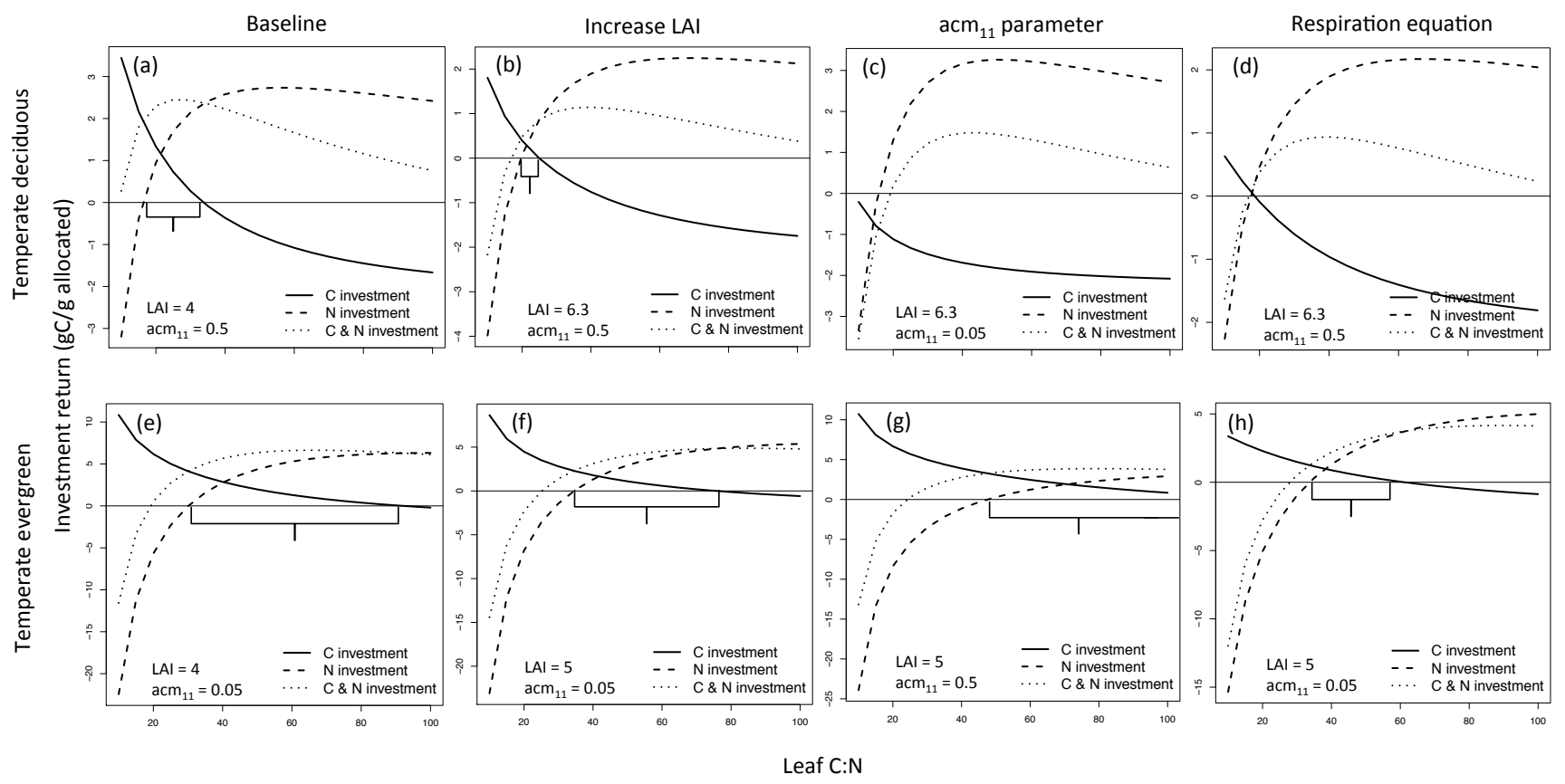

Figure 4. Sensitivity of the range of leaf $\mathrm{C}: \mathrm{N}$ with positive $\mathrm{C}$ returns on marginal investment of leaf $\mathrm{C}$ and leaf $\mathrm{N}$ for a temperate deciduous (a-d) and an evergreen (e-h) forest. The range of leaf $\mathrm{C}: \mathrm{N}$ with positive returns increases with leaf area index (a vs. b; e vs. f) and depends on the acm11 parameter (a vs. c; e vs. g), and the non-linearity of the leaf respiration parameterization (a vs. d; e vs. h). (a and e) use the $\log -\log$ relationship between $\mathrm{N}$ concentration and leaf respiration from Reich et al. (2008) and (d and h) use the linear relationship from Ryan (1991). Brackets indicate range of leaf $C: N$ where leaf $C: N$ can vary based on $N$ status of the plant.

plant trait database (temperate deciduous $<$ tropical evergreen $<$ temperate evergreen). Capturing these broad biome patterns with ACONITE indicates potential for future research that uses the patterns in leaf mass per area, leaflifespan, and climate to simulate spatial patterns in leaf $\mathrm{C}: \mathrm{N}$. However, further exploration into the requirement for two different $\mathrm{acm}_{11}$ parameters for different leaf traits is needed . The calibration of the photosynthesis algorithm (ACM) used here was derived based on a fixed exponential decline in $\mathrm{N}$ content through the canopy in the SPA model, with no variation linked to leaf traits, and without exploring more extreme ratios of LAI to foliar $\mathrm{N}$. The correction introduced using the $\mathrm{acm}_{11}$ parameter requires further work, based on more detailed SPA simulations, to resolve the complex interactions of $\mathrm{C}$ and $\mathrm{N}$ allocation within plant canopies.

Simulated GPP and NPP generally compared well to observations (Table 7). In the tropics, simulated NPP was within in the estimates for 10 Amazonian forests (ACONITE: 1423; observed $930-1700 \mathrm{gC} \mathrm{m}^{-2} \mathrm{yr}^{-1}$ ) (Aragão et al., 2009). For the temperate simulations, modeled NPP also matched estimates for deciduous stands at Harvard Forest, $659 \mathrm{gC} \mathrm{m}^{-2} \mathrm{yr}^{-1}$ (Waring et al., 1998). The estimates of GPP in ACONITE are also consistent with independent estimates, for deciduous stands in Harvard Forest, $1246 \mathrm{gC} \mathrm{m}^{-2} \mathrm{yr}^{-1}$ (Waring et al., 1998) and for forests in Amazonia, 3094-3138 $\mathrm{gC} \mathrm{m}^{-2} \mathrm{yr}^{-1}$ (Fisher et al., 2007).
ACONITE simulated observed biome level patterns (Cleveland et al., 1999) in $\mathrm{N}$ fixation where $\mathrm{N}$ fixation at steady state in the tropics was $>10$ times $\mathrm{N}$ fixation in the temperate region. $\mathrm{N}$ fixation in ACONITE is governed by two temporal scales. The most immediate occurs when the internal capacity to store $\mathrm{C}$ is exceeded and the internal capacity to store $\mathrm{N}$ is not met. This results in higher $\mathrm{N}$ fixation in ecosystems with large energy inputs relative to $\mathrm{N}$ available in the soil. At longer time scales, plants increase allocation to roots if there is a larger return of $\mathrm{N}$ for $\mathrm{C}$ allocated to roots than $\mathrm{C}$ allocated to fixation. Increasing root mass increases the uptake of $\mathrm{N}$ and increases the internal store of $\mathrm{N}$, thus decreasing $\mathrm{N}$ fixation. The dependence of $\mathrm{N}$ fixation on both marginal $\mathrm{N}$ yield for $\mathrm{C}$ allocation and the total availability of $\mathrm{C}$ and $\mathrm{N}$ in internal storage pools combines recent $\mathrm{N}$ fixation modeling approaches that used marginal yields (MEL: Rastetter et al., 2013) and $\mathrm{N}$ demand scaled by light (energy) availability (Gerber et al., 2010).

The balance between growth and respiration by plants determines the production of biomass. The fraction of photosynthesis used for growth is known as the $\mathrm{C}$ use efficiency (CUE), equivalent to the NPP : GPP ratio. CUE is challenging to determine, but initial estimates suggested it might be a conservative quantity for temperate forests, with a value of $\sim 0.5$ (Waring et al., 1998). Subsequent studies have suggested that CUE differs by biome, being lower in tropical 


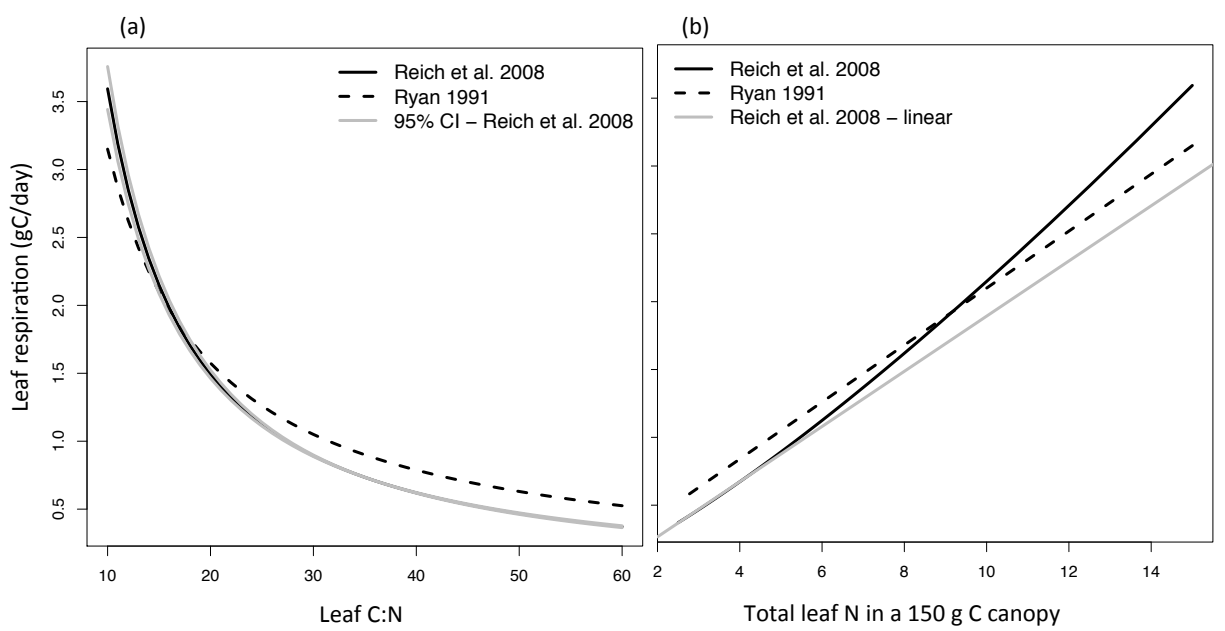

Figure 5. Leaf respiration increases non-linearly with leaf $\mathrm{N}$ using the Reich et al. (2008) parameterization and linearly with leaf $\mathrm{N}$ using the Ryan (1991) parameterization. Total canopy leaf respiration for a plant with $150 \mathrm{~g} \mathrm{C} \mathrm{m}^{-2}$ canopy is shown as a function of leaf $\mathrm{N}$, expressed on a leaf C: $\mathrm{N}$ basis (a) and a total canopy leaf $\mathrm{N}$ basis (b). The $95 \%$ uncertainty from Reich et al. (2008) is shown as gray lines in (a). The non-linearity of the Reich et al. (2008) equation is illustrated by extrapolating the initial slope (gray line) in (b).

forests, (Chambers et al., 2004) and lower in older (but not younger) boreal forests (Goulden et al., 2011). The range of CUE for the three ecosystems in this study, 0.44-0.51, is close to the suggested conservative value. Our tropical estimate (0.45), while lower than the temperate estimate, does not match the lower value reported for tropical forests (0.3). Our analysis (Table 8) shows relatively low sensitivity of CUE to several parameters linked to photosynthesis and respiration. A more complete analysis of CUE sensitivity, linked to detailed $\mathrm{C}$ and $\mathrm{N}$ budgets measurements for tropical ecosystems, would be a valuable next step.

\subsection{Critical determinants of emergent properties in ACONITE}

One of the most sensitive parameters was the slope of the $\log -\log$ relationship between leaf $\mathrm{N}$ concentration and respiration rates (Table 8). Higher slopes led to increased leaf $\mathrm{C}: \mathrm{N}$ and LAI. The log-log relationship between mass-based respiration and mass-based $\mathrm{N}$ concentration was derived from the analysis of a global plant trait database in Reich et al. (2008). This study found that the slope of the relationship was similar among plant organs (leaves, roots, and wood) and plant functional types (gymnosperms, angiosperms, grasses), and that the slope was greater than 1. A slope greater than 1 indicates a higher respiratory cost for $\mathrm{N}$ as $\mathrm{N}$ concentrations increase (lower leaf $\mathrm{C}: \mathrm{N}$ ), potentially due to a greater proportion of $\mathrm{N}$ allocated to metabolically active proteins and faster turnover rate of protein (Reich et al., 2008). This elevated respiratory cost at low leaf $\mathrm{C}: \mathrm{N}$ is important for defining a lower bound for leaf $\mathrm{C}: \mathrm{N}$. This exponentially increasing respiratory cost as the leaf $\mathrm{C}: \mathrm{N}$ increases led to a higher leaf $\mathrm{C}: \mathrm{N}$ where the marginal $\mathrm{C}$ return for $\mathrm{N}$ allocation to leaves is zero. The elevated respiratory costs at low leaf $\mathrm{C}: \mathrm{N}$ is considerably larger when using the power-law scaling in Reich et al. (2008) than the more widely used linear scaling from Ryan (1991) (Fig. 5). We suggest that, when using the trade-off between photosynthesis and respiration to calculate $\mathrm{N}$ allocation to leaves, ecosystem and Earth System models explore the sensitivity of $\mathrm{N}$ allocation to non-linearity in the $\mathrm{N}$-respiration relationship.

Another sensitive parameter $\left(\mathrm{acm}_{2}\right)$ describes the slope of relationship between GPP and day-length in the photosynthesis algorithm (ACM). $\mathrm{acm}_{2}$ functions as a simple linear scalar of GPP, where the scaling magnitude depends on daylength. Therefore GPP increases in proportion to the change in the $\mathrm{acm}_{2}$ parameter. Because of the large sensitivity of total vegetation $\mathrm{C}$, NPP, and $\mathrm{N}$ fixation on photosynthesis, these processes have significant sensitivity to $\mathrm{acm}_{2}$.

\subsection{ACONITE caveats and areas for future development}

The ACONITE simulations presented here include key caveats. First, the results presented are for steady-state conditions. Additional evaluation is needed of the timescales over which the $\mathrm{C}-\mathrm{N}$ feedbacks evolve. These feedbacks influence the rate of change in leaf $\mathrm{C}: \mathrm{N}, \mathrm{LAI}$ and $\mathrm{N}$ fixation over time. Accurately modeling the time-scale of $\mathrm{C}-\mathrm{N}$ feedbacks is a common challenge for all ecosystem and Earth System models with $\mathrm{C}$ and $\mathrm{N}$ cycles. Second, the version of ACONITE we present here only applies to ecosystems without water limitation of photosynthesis and decomposition. This is a reasonable assumption for the sites used to evaluate models (Eastern temperate US and central Amazon) but including a simple water cycle is required for global 
application of ACONITE. Third, using the parameterization described above, $\mathrm{N}$ limitation is a transient property and was not present at steady state. In ACONITE, over long-time scales without disturbance, the ecosystem is able to entrain enough $\mathrm{N}$ from $\mathrm{N}$ fixation and $\mathrm{N}$ deposition to overcome $\mathrm{N}$ limitation. $\mathrm{N}$ limitation at steady-state can be parameterized in ACONITE by increasing the loss of $\mathrm{N}$ that is not controllable by plant or microbial uptake (Menge, 2011). In ACONITE, this processes is represented by the leaching of DON that is produced through the turnover of soil organic N (parameter: DON_leach_prop). Finally, as a biogeochemical model, ACONITE does not include plant demographic dynamics and, therefore, does not include the dynamics of leaf traits (leaf mass per area and leaf-lifespan) that would change over time through forest succession. Future model development can expand the fundamentals of ACONITE (optimized dynamic LAI, leaf $\mathrm{C}: \mathrm{N}, \mathrm{CUE}$, and $\mathrm{N}$ fixation based on marginal returns on investment) to address these caveats.

\subsection{Potential applications for ACONITE}

The ability to constrain LAI and have spatially and temporally variable leaf $\mathrm{C}: \mathrm{N}$, features of the ACONITE model, are challenges for ecosystem and Earth System models. For example, the O-CN Earth System model includes dynamic leaf $\mathrm{C}: \mathrm{N}$ but requires parameters for each plant functional type that describe the maximum, minimum, and average leaf $\mathrm{C}: \mathrm{N}$ (Zaehle and Friend, 2010). Other ecosystem models, like the PnET-CN model, require the parameterization of maximum and minimum leaf C:N (Aber et al., 1997). Even a recently developed model that shows promise for defining the optimal allocation of leaf $\mathrm{N}$ among structural, storage, photosynthetic, and respiration $\mathrm{N}$ requires the parameterization of the total leaf functional leaf $\mathrm{N}$ (Xu et al., 2012) Here we presented a framework using marginal yields of investment to simulate dynamic leaf $\mathrm{C}: \mathrm{N}$ without the two or three additional parameters per plant functional type that other models have required. Other ecosystem models include dynamic allocation of $\mathrm{C}$ to leaves and roots based on marginal yields (Multiple Element Limitation model: Rastetter et al., 2013) but use fixed $\mathrm{C}: \mathrm{N}$ of tissues to calculate $\mathrm{N}$ allocation. The marginal allocation of both leaf $\mathrm{C}$ and $\mathrm{N}$ separately based on marginal yields extends the allocation concepts in the MEL model to the allocation of multiple elements. Finally, the dynamic allocation of leaf C (LAI) based on marginal yields can potentially help address issues with higher than observed LAI in Earth System models that results from simply calculating LAI based on the balance of $\mathrm{C}$ allocation to leaves and leaf turnover (Lawrence et al., 2011; Oleson et al., 2013) or without specifying a maximum LAI parameter for each plant function type (Gerber et al., 2010). Overall, the marginal yield framework used to allocate leaf $\mathrm{C}$ and $\mathrm{N}$ used in ACONITE is designed for application in Earth System models, because it requires minimal parameterization and can be applied to both seasonal and non-seasonal environments and both deciduous and evergreen life history strategies. Application to Earth System models will be associated with additional computational costs for their land surface components, associated with calculating marginal yields for allocation of $\mathrm{C}$ and $\mathrm{N}$.

In the current version of ACONITE, the respiration of excess labile $\mathrm{C}$ is used for $\mathrm{N}$ fixation when $\mathrm{N}$ is limiting. $\mathrm{Fu}-$ ture model extensions can more mechanistically allocate this respired $\mathrm{C}$ to different forms of $\mathrm{N}$, based on the uptake cost of each form. For example, the Fixation and Uptake of Nitrogen (FUN) model provides an example of how to allocate $\mathrm{C}$ respiration to $\mathrm{N}$ uptake, based on the comparison of $\mathrm{C}$ costs of $\mathrm{N}$ fixation, active $\mathrm{N}$ uptake from inorganic forms in the soil, and retranslocation (Fisher et al., 2010). The FUN model could be further expanded to include marginal returns of $\mathrm{N}$ on $\mathrm{C}$ allocation to soil microbes (soil priming) or mycorrhizal allocation. Combining elements of ACONITE and FUN would allow for more mechanistic predictions of both LAI and leaf $\mathrm{C}: \mathrm{N}$ from ACONITE and the allocation of respiration to $\mathrm{N}$ uptake from FUN.

In addition to applications to Earth System Modeling, the ACONITE structure is designed for parameter estimation and uncertainty estimation through assimilation of ecosystem data (Williams et al., 2009). Data-assimilation allows for the formal integration of multiple observations types and preexisting (prior) parameter estimates, with formal propagation of error statistics. Most applications of data-assimilation for modeling the $\mathrm{C}$ cycle have used models with only the $\mathrm{C}$ cycle or the $C$ and water cycles represented (Fox et al., 2009). Clearly, adding a $\mathrm{N}$ cycle increases the model complexity with additional parameters and equations. However adding an $\mathrm{N}$ cycle may also increase the constraints provided by data, because of the tight coupling of the $\mathrm{C}$ and $\mathrm{N}$ cycles and additional data related to the $\mathrm{N}$ cycle that is available for parameter estimation. Carbon only models currently suffer from a lack of constraint on their behaviors (Hill et al., 2012), which may be relieved by the inclusion of $\mathrm{N}$ cycle interactions. Whether the constraints provided by the $\mathrm{N}$ cycle on $\mathrm{C}$ predictions outweigh the cost of the greater model complexity is an important question for advancing $\mathrm{C}$ predictions, particularly in $\mathrm{N}$ limited regions of the world.

Overall, ACONITE represents a simple approach to modeling both the $\mathrm{C}$ and $\mathrm{N}$ cycles that simulates emergent properties (leaf $\mathrm{C}: \mathrm{N}$, maximum LAI, CUE, and $\mathrm{N}$ fixation) without using specific parameters to define properties. These emergent properties increase the flexibility of model applications while reducing total number of parameters required to be estimated through data-assimilation. ACONITE also has a relatively low computational load which allows a rapid and detailed exploration of its parameter space, required for Monte Carlo assimilation approaches. In this study we have shown qualitative similarities in model output with selected biome data. A more comprehensive and ecological challenging study would be to use DA approaches to formally estimate parameter uncertainty that complements the parameter 
sensitivity analysis reported here. Such a study would apply ACONITE at many more well studied locations with time series ( $>$ decadal) observations of $\mathrm{C}$ and $\mathrm{N}$ stocks and fluxes, LAI data and local plant trait data on leaf $\mathrm{C}: \mathrm{N}$ and leaf mass per area. Such a study would provide more robust tests of the theory behind ACONITE and underpin a further activity for global data assimilation, whereby $\mathrm{C}$ and $\mathrm{N}$ cycles at global scales are analyzed, using ACONITE, for consistency with both optimization theory and observations from global databases and from Earth observation.

\section{Code availability}

Code is available in the Supplement or through contacting the authors: R. Q. Thomas (rqthomas@vt.edu) or M. Williams (mat.williams@ed.ac.uk)

\section{The Supplement related to this article is available online at doi:10.5194/gmd-7-2015-2014-supplement.}

Acknowledgements. We greatly thank Gordon Bonan and the National Center for Atmospheric Research, Boulder, CO, for support while developing the model. We thank Edward Rastetter and Rosie Fisher for discussions that helped focus our ideas. We greatly appreciate the meteorology data provided by the Harvard Forest LTER and that from Manaus, kindly provided by Alessandro Araújo and Antonio Donato Nobre, for model forcing. National Science Foundation Awards AGS-1020767 and EF-1048481 partially supported the project. Support to Mat Williams was provided by the Natural Environmental Research Council Award EARTH010003. Virginia Tech's Open Access Subvention Fund helped financially support the publication of this article. We also thank two anonymous reviewers for their helpful comments which improved this paper.

Edited by: C. Sierra

\section{References}

Aber, J. D., Ollinger, S. V., and Driscoll, C. T.: Modeling nitrogen saturation in forest ecosystems in response to land use and atmospheric deposition, Ecol. Mod., 101, 61-78, 1997.

Aragão, L. E. O. C., Malhi, Y., Metcalfe, D. B., Silva-Espejo, J. E., Jiménez, E., Navarrete, D., Almeida, S., Costa, A. C. L., Salinas, N., Phillips, O. L., Anderson, L. O., Alvarez, E., Baker, T. R., Goncalvez, P. H., Huamán-Ovalle, J., Mamani-Solórzano, M., Meir, P., Monteagudo, A., Patiño, S., Peñuela, M. C., Prieto, A., Quesada, C. A., Rozas-Dávila, A., Rudas, A., Silva Jr., J. A., and Vásquez, R.: Above- and below-ground net primary productivity across 10 Amazonian forests on contrasting soils, Biogeosciences, 6, 2759-2778, doi:10.5194/bg-6-2759-2009, 2009.

Bloom, A. J., Chapin III, F. S., and Mooney, H. A.: Resource limitation in plants - an economic analogy, Ann. Rev. Ecol. System., 16, 363-392, 1985.
Cannell, M. G. R. and Thornley, J. H. M.: Modelling the components of plant respiration: Some guiding principles, Ann. Botany, $85,45-54,2000$.

Chambers, J. Q., Tribuzy, E. S., Toledo, L. C., Crispim, B. F., Higuchi, N., Santos, J. d., Araújo, A. C., Kruijt, B., Nobre, A. D., and Trumbore, S. E.: Respiration from a tropical forest ecosystem: partitioning of sources and low carbon use efficiency, Ecol. Appl., 14, 72-88, 2004.

Cleveland, C. C., Townsend, A. R., Schimel, D. S., Fisher, H., Howarth, R. W., Hedin, L. O., Perakis, S. S., Latty, E. F., Von Fischer, J. C., and Elseroad, A.: Global patterns of terrestrial biological nitrogen (N2) fixation in natural ecosystems, Global Biogeochem. Cy., 13, 623-645, 1999.

Comas, L. and Eissenstat, D.: Linking fine root traits to maximum potential growth rate among 11 mature temperate tree species, Function. Ecol., 18, 388-397, 2004.

de Vries, W., Solberg, S., Dobbertin, M., Sterba, H., Laubhahn, D., Reinds, G. J., Nabuurs, G.-J., Gundersen, P., and Sutton, M. A.: Ecologically implausible carbon response?, Nature, 451, E1-E3, 2008.

Drake, J. E., Gallet-Budynek, A., Hofmockel, K. S., Bernhardt, E. S., Billings, S. A., Jackson, R. B., Johnsen, K. S., Lichter, J., McCarthy, H. R., and McCormack, M. L.: Increases in the flux of carbon belowground stimulate nitrogen uptake and sustain the long-term enhancement of forest productivity under elevated $\mathrm{CO}_{2}$, Ecol. Lett., 14, 349-357, 2011.

Erisman, J. W., Galloway, J. N., Seitzinger, S., Bleeker, A., Dise, N. B., Petrescu, A. M. R., Leach, A. M., and de Vries, W.: Consequences of human modification of the global nitrogen cycle, Philos. Trans. Roy. Soc., 368, 1621, doi:10.1098/rstb.2013.0116, 2013.

Fahey, T., Siccama, T., Driscoll, C., Likens, G., Campbell, J., Johnson, C., Battles, J., Aber, J., Cole, J., and Fisk, M.: The biogeochemistry of carbon at Hubbard Brook, Biogeochemistry, 75 , 109-176, 2005.

Fisher, J. B., Sitch, S., Malhi, Y., Fisher, R. A., Huntingford, C., and Tan, S.-Y.: Carbon cost of plant nitrogen acquisition: A mechanistic, globally applicable model of plant nitrogen uptake, retranslocation, and fixation, Global Biogeochem. Cy., 24 GB1014, doi:10.1029/2009GB003621, 2010.

Fisher, R. A., Williams, M., Da Costa, A. L., Malhi, Y., Da Costa, R. F., Almeida, S., and Meir, P.: The response of an Eastern Amazonian rain forest to drought stress: results and modelling analyses from a throughfall exclusion experiment, Glob. Change Biol., 13, 2361-2378, 2007.

Fox, A. M., Williams, M., Richardson, A. D., Cameron, D., Gove, J., Reichstein, M., Quaife, T., Ricciuto, D., Tomelleri, E., Trudinger, C. M., and Van Wijk, M. T.: The REFLEX project: comparing different algorithms and implementations for the inversion of a terrestrial ecosystem model against eddy covariance data, Agr. Forest Meteorol., 149, 1597-1615, 2009.

Gerber, S., Hedin, L. O., Oppenheimer, M., Pacala, S. W., and Shevliakova, E.: Nitrogen cycling and feedbacks in a global dynamic land model, Global Biogeochem. Cy., 24, GB1001, doi:10.1029/2008GB003336, 2010.

Goulden, M. L., McMillan, A., Winston, G., Rocha, A., Manies, K., Harden, J. W., and Bond-Lamberty, B.: Patterns of NPP, GPP, respiration, and NEP during boreal forest succession, Glob. Change Biol., 17, 855-871, 2011. 
Gruber, N. and Galloway, J. N.: An Earth-system perspective of the global nitrogen cycle, Nature, 451, 293-296, 2008.

Gutschick, V. P.: Evolved strategies in nitrogen acquisition by plants, American Naturalist, 118, 607-637, 1981.

Hilbert, D. W. and Reynolds, J. F.: A model allocating growth among leaf proteins, shoot structure, and root biomass to produce balanced activity, Ann. Botany, 68, 417-425, 1991.

Hill, T. C., Ryan, E., and Williams, M.: The use of $\mathrm{CO}_{2}$ flux time series for parameter and carbon stock estimation in carbon cycle research, Glob. Change Biol., 18, 179-193, 2012.

IPCC: Climate Change 2013: The Physical Science Basis, IPCC, Cambridge, 2013.

Kattge, J., Diaz, S., Lavorel, S., Prentice, I., Leadley, P., Bönisch, G., Garnier, E., Westoby, M., Reich, P. B., and Wright, I.: TRY-a global database of plant traits, Glob. Change Biol., 17, 29052935, 2011.

Keenan, T. F., Carbone, M. S., Reichstein, M., and Richardson, A. D.: The model-data fusion pitfall: assuming certainty in an uncertain world, Oecologia, 167, 587-597, 2011.

Kruijt, B., Elbers, J. A., von Randow, C., Araújo, A. C., Oliveira, P. J., Culf, A., Manzi, A. O., Nobre, A. D., Kabat, P., and Moors, E. J.: The robustness of eddy correlation fluxes for Amazon rain forest conditions, Ecol. Appl., 14, 101-113, 2004.

Lawrence, D. M., Oleson, K. W., Flanner, M. G., Thornton, P. E., Swenson, S. C., Lawrence, P. J., Zeng, X., Yang, Z. L., Levis, S., and Sakaguchi, K.: Parameterization improvements and functional and structural advances in version 4 of the Community Land Model, J. Adv. Model. Earth Syst., 3, M03001, doi:10.1029/2011MS000045, 2011.

Le Quere, C., Raupach, M. R., Canadell, J. G., Marland, G., Bopp, L., Ciais, P., Conway, T. J., Doney, S. C., Feely, R. A., Foster, P., Friedlingstein, P., Gurney, K., Houghton, R. A., House, J. I., Huntingford, C., Levy, P. E., Lomas, M. R., Majkut, J., Metzl, N., Ometto, J. P., Peters, G. P., Prentice, I. C., Randerson, J. T., Running, S. W., Sarmiento, J. L., Schuster, U., Sitch, S., Takahashi, T., Viovy, N., van der Werf, G. R., and Woodward, F. I.: Trends in the sources and sinks of carbon dioxide, Nat. Geosci., 2, 831-836, 2009.

Linder, S. and Troeng, E.: Photosynthesis and transpiration of 20year-old Scots pine, Ecol. Bull., 32, 165-181, 1980.

Magnani, F., Mencuccini, M., Borghetti, M., Berbigier, P., Berninger, F., Delzon, S., Grelle, A., Hari, P., Jarvis, P. G., Kolari, P., Kowalski, A. S., Lankreijer, H., Law, B. E., Lindroth, A., Loustau, D., Manca, G., Moncrieff, J. B., Rayment, M., Tedeschi, V., Valentini, R., and Grace, J.: The human footprint in the carbon cycle of temperate and boreal forests, Nature, 447, 849-851, 2007.

Mahecha, M. D., Reichstein, M., Carvalhais, N., Lasslop, G., Lange, H., Seneviratne, S. I., Vargas, R., Ammann, C., Arain, M. A., Cescatti, A., Janssens, I. A., Migliavacca, M., Montagnani, L., and Richardson, A. D.: Global Convergence in the Temperature Sensitivity of Respiration at Ecosystem Level, Science, 329, 838-840, 2010.

Manzoni, S., Trofymow, J. A., Jackson, R. B., and Porporato, A.: Stoichiometric controls on carbon, nitrogen, and phosphorus dynamics in decomposing litter, Ecol. Monogr., 80, 89-106, 2010.

McClaugherty, C. A., Pastor, J., Aber, J. D., and Melillo, J. M.: Forest litter decomposition in relation to soil nitrogen dynamics and litter quality, Ecol., 66, 266-275, 1985.
McCormack, M. L., Eissenstat, D. M., Prasad, A. M., and Smithwick, E. A. H.: Regional scale patterns of fine root lifespan and turnover under current and future climate, Glob. Change Biol., 19, 1697-1708, 2013.

Menge, D. N.: Conditions under which nitrogen can limit steadystate net primary production in a general class of ecosystem models, Ecosystems, 14, 519-532, 2011.

Munger, W. and Wofsy, S.: Canopy-Atmosphere Exchange of Carbon, Water and Energy at Harvard Forest EMS Tower since 1991, Network, L. T. E. R., 1999.

Norby, R. J., Warren, J. M., Iversen, C. M., Medlyn, B. E., and McMurtrie, R. E.: CO2 enhancement of forest productivity constrained by limited nitrogen availability, Proc. Natl. Aca. Sci., 107, 19368-19373, 2010.

Nowak, R. S., Ellsworth, D. S., and Smith, S. D.: Functional responses of plants to elevated atmospheric CO2 - do photosynthetic and productivity data from FACE experiments support early predictions?, New Phytologist, 162, 253-280, 2004.

Nye, P. H. and Tinker, P. B.: Solute movement in the soil-root system, Blackwell Scientific, Oxford, UK, 1977.

Oleson, K., Lawrence, D. M., Bonan, G. B., Drewniak, B., Huang, M., Koven, C. D., Levis, S., Li, F., Riley, W. J., Subin, Z. M., Swenson, S. C., Thornton, P. E., Bozbiyik, A., Fisher, R., Heald, C. L., Kluzek, E., Lamarque, J. F., Lawrence, P. J., Leung, L. R., Lipscomb, W., Muszala, S., Ricciuto, D. M., Sacks, W., Sun, Y., Tang, J., and Yang, Z. L.: Technical Description of version 4.5 of the Community Land Model (CLM), NCAR Technical Note NCAR, Boulder, Co., 420 pp., 2013.

Parton, W. J., Scurlock, J. M. O., Ojima, D. S., Gilmanov, T. G., Scholes, R. J., Schimel, D. S. K., Menaut, J. C., Seastadt, T., Moya, E. G., Kalmnalrut, A., and Kinyamario, J. I.: Observations and modeling of biomass and soils organic matter dynamics for the grassland biome worldwide, Global Biogeochem. Cy., 7, 785809, 1993.

Pinder, R. W., Davidson, E. A., Goodale, C. L., Greaver, T. L., Herrick, J. D., and Liu, L.: Climate change impacts of US reactive nitrogen, Proc. Natl. Aca. Sci., 109, 7671-7675, 2012.

Rastetter, E. B., Vitousek, P. M., Field, C., Shaver, G. R., Herbert, D., and Ågren, G. I.: Resource optimization and symbiotic N fixation, Ecosystems, 4, 369-388, 2001.

Rastetter, E. B., Yanai, R. D., Thomas, R. Q., Vadeboncoeur, M. A., Fahey, T. J., Fisk, M. C., Kwiatkowski, B. L., and Hamburg, S. P.: Recovery from disturbance requires resynchronization of ecosystem nutrient cycles, Ecol. Appl., 23, 621-642, 2013.

Reich, P. B., Walters, M. B., Ellsworth, D. S., and Uhl, C.: Photosynthesis-nitrogen relations in Amazonian tree species. I. Patterns among species and communities, Oecologia, 97, 62-72, 1994.

Reich, P. B., Tjoelker, M. G., Machado, J.-L., and Oleksyn, J.: Universal scaling of respiratory metabolism, size and nitrogen in plants, Nature, 439, 457-461, 2006.

Reich, P. B., Tjoelker, M. G., Pregitzer, K. S., Wright, I. J., Oleksyn, J., and Machado, J. L.: Scaling of respiration to nitrogen in leaves, stems and roots of higher land plants, Ecol. Lett., 11, 793801, 2008.

Ryan, M. G.: A simple method for estimating gross carbon budgets for vegetation in forest ecosystems., Tree Physiol., 9, 255-266, 1991. 
Schimel, D. S., Braswell, B., and Parton, W.: Equilibration of the terrestrial water, nitrogen, and carbon cycles, Proc. Natl. Aca. Sci., 94, 8280-8283, 1997.

Shaver, G. R. and Chapin III, F. S.: Long-term responses to factorial, NPK fertilizer treatment by Alaskan wet and moist tundra sedge species, Ecography, 18, 259-275, 1995.

Shaver, G. R., Street, L. E., Rastetter, E. B., Van Wijk, M. T., and Williams, M.: Functional convergence in regulation of net $\mathrm{CO}_{2}$ flux in heterogeneous tundra landscapes in Alaska and Sweden, J. Ecol., 95, 802-817, 2007.

Smith, B., Wårlind, D., Arneth, A., Hickler, T., Leadley, P., Siltberg, J., and Zaehle, S.: Implications of incorporating $\mathrm{N}$ cycling and $\mathrm{N}$ limitations on primary production in an individualbased dynamic vegetation model, Biogeosciences, 11, 20272054, doi:10.5194/bg-11-2027-2014, 2014.

Sokolov, A. P., Kicklighter, D. W., Melillo, J. M., Felzer, B. S., Schlosser, C. A., and Cronin, T. W.: Consequences of Considering Carbon-Nitrogen Interactions on the Feedbacks between Climate and the Terrestrial Carbon Cycle, J. Climate, 21, 37763796, 2008.

Street, L. E., Shaver, G. R., Rastetter, E. B., van Wijk, M. T., Kaye, B. A., and Williams, M.: Incident radiation and the allocation of nitrogen within Arctic plant canopies: implications for predicting gross primary productivity, Glob. Change Biol., 18, 2838-2852, 2012

Thomas, R. Q., Canham, C. D., Weathers, K. C., and Goodale, C. L.: Increased tree carbon storage in response to nitrogen deposition in the US, Nat. Geosci., 3, 13-17, 2010.

Thornton, P. E. and Rosenbloom, N. A.: Ecosystem model spin-up: Estimating steady state conditions in a coupled terrestrial carbon and nitrogen cycle model, Ecol. Mod., 189, 25-48, 2005.

Thornton, P. E., Lamarque, J.-F., Rosenbloom, N. A., and Mahowald, N. M.: Influence of carbon-nitrogen cycle coupling on land model response to $\mathrm{CO} 2$ fertilization and climate variability, Global Biogeochem. Cy., 21, GB4018, doi:10.1029/2006gb002868, 2007.

Tilman, D., Cassman, K. G., Matson, P. A., Naylor, R., and Polasky, S.: Agricultural sustainability and intensive production practices, Nature, 418, 671-677, 2002.

Vitousek, P. M., Porder, S., Houlton, B. Z., and Chadwick, O. A.: Terrestrial phosphorus limitation: mechanisms, implications, and nitrogen-phosphorus interactions, Ecol. Appl., 20, 5-15, 2010.

Wang, Y. P., Law, R. M., and Pak, B.: A global model of carbon, nitrogen and phosphorus cycles for the terrestrial biosphere, Biogeosciences, 7, 2261-2282, doi:10.5194/bg-7-2261-2010, 2010.

Wania, R., Meissner, K. J., Eby, M., Arora, V. K., Ross, I., and Weaver, A. J.: Carbon-nitrogen feedbacks in the UVic ESCM, Geosci. Model Dev., 5, 1137-1160, doi:10.5194/gmd-5-11372012, 2012.

Waring, R. H. and Schlesinger, W. H.: Forest ecosystems: concepts and management, Academic Press, Orlando, Florida, USA, 1985.

Waring, R. H., Landsberg, J. J., and Williams, M.: Net primary production of forests: a constant fraction of gross primary production?, Tree Physiol., 18, 129-134, 1998.

White, M. A., Thornton, P. E., Running, S. W., and Nemani, R. R.: Parameterization and sensitivity analysis of the BIOME-BGC terrestrial ecosystem model: net primary production controls, Earth Interactions, 4, 1-85, 2000.
Williams, M. and Rastetter, E. B.: Vegetation characteristics and primary productivity along an arctic transect: implications for scaling-up, J. Ecol., 87, 885-898, 1999.

Williams, M. and Yanai, R. D.: Multi-dimensional sensitivity analysis and ecological implications of a nutrient uptake model, Plant Soil, 180, 311-324, 1996.

Williams, M., Law, B. E., Anthoni, P. M., and Unsworth, M.: Use of a simulation model and ecosystem flux data to examine carbonwater interactions in ponderosa pine, Tree Physiol., 21, 287-298, 2001.

Williams, M., Rastetter, E. B., Fernandes, D. N., Goulden, M. L., Wofsy, S. C., Shaver, G. R., Melillo, J. M., Munger, J. W., Fan, S.-M., and Nadelhoffer, K. J.: Modelling the soil-plantatmosphere continuum in a Quercus-Acer stand at Harvard Forest: the regulation of stomatal conductance by light, nitrogen and soil/plant hydraulic properties, Plant Cell Environ., 19, 911-927, 1996.

Williams, M., Rastetter, E. B., Fernandes, D. N., Goulden, M. L., Shaver, G. R., and Johnson, L. C.: Predicting gross primary productivity in terrestrial ecosystems, Ecol. Appl., 7, 882-894, 1997.

Williams, M., Schwarz, P., Law, B. E., Irvine, J., and Kurpius, M. R.: An improved analysis of forest carbon dynamics using data assimilation, Glob. Change Biol., 11, 89-105, 2005.

Williams, M., Richardson, A. D., Reichstein, M., Stoy, P. C., Peylin, P., Verbeeck, H., Carvalhais, N., Jung, M., Hollinger, D. Y., Kattge, J., Leuning, R., Luo, Y., Tomelleri, E., Trudinger, C. M., and Wang, Y. -P.: Improving land surface models with FLUXNET data, Biogeosciences, 6, 1341-1359, doi:10.5194/bg-6-1341-2009, 2009.

Wright, I. J., Reich, P. B., Westoby, M., Ackerly, D. D., Baruch, Z., Bongers, F., Cavender-Bares, J., Chapin, T., Cornelissen, J. H. C., Diemer, M., Flexas, J., Garnier, E., Groom, P. K., Gulias, J., Hikosaka, K., Lamont, B. B., Lee, T., Lee, W., Lusk, C., Midgley, J. J., Navas, M.-L., Niinemets, U., Oleksyn, J., Osada, N., Poorter, H., Poot, P., Prior, L., Pyankov, V. I., Roumet, C., Thomas, S. C., Tjoelker, M. G., Veneklaas, E. J., and Villar, R.: The worldwide leaf economics spectrum, Nature, 428, 821-827, 2004.

Xu, C., Fisher, R., Wullschleger, S. D., Wilson, C. J., Cai, M., and McDowell, N. G.: Toward a mechanistic modeling of nitrogen limitation on vegetation dynamics, PloS one, 7, e37914, 2012.

$\mathrm{Xu}, \mathrm{R}$. I. and Prentice, I. C.: Terrestrial nitrogen cycle simulation with a dynamic global vegetation model, Glob. Change Biol., 14, 1745-1764, 2008.

Zaehle, S. and Friend, A. D.: Carbon and nitrogen cycle dynamics in the O-CN land surface model: 1. Model description, site-scale evaluation, and sensitivity to parameter estimates, Global Biogeochem. Cy., 24, GB1005, doi:10.1029/2009GB003521, 2010.

Zaehle, S., Friedlingstein, P., and Friend, A. D.: Terrestrial nitrogen feedbacks may accelerate future climate change, Geophys. Res. Lett., 37, L01401, doi:10.1029/2009g1041345, 2010. 